\title{
TUTELA ANTECIPADA, TUTELA CAUTELAR E TUTELA DA EVIDÊNCIA COMO ESPÉCIES DE TUTELA PROVISÓRIA NO NOVO CÓDIGO DE PROCESSO CIVIL ${ }^{1}$
}

\section{TUTELA ANTICIPATA, TUTELA CAUTELARE E TUTELA DELLA EVIDENZA COME SPECIE DI TUTELA PROVVISORIA NEL NUOVO CODICE DI PROCESSO CIVILE}

Igor Raatz Doutorando e mestre em Direito pela UNISINOS. Especialista em Direito Processual Civil pela Academia Brasileira de Direito Processual Civil. Membro do Instituto Iberoamericano de derecho procesal. Professor em cursos de graduação e pós-graduação. Advogado. Porto Alegre/RS. igorraatz@gmail.com

Natascha Anchieta Mestre em Direito pela UNISINOS. Especialista em Direito pela Associação dos Juízes do Estado do Rio Grande do Sul - AJURIS. Professora em cursos de pósgraduação. Advogada. Porto Alegre/RS.

RESUMO: O presente ensaio visa a examinar o tema da "tutela provisória", prevista no Livro V da Parte Geral do Novo Código de Processo Civil como gênero do qual são espécies a tutela cautelar, a tutela antecipada e a tutela da evidência. Objetiva-se esclarecer o esquema conceitual adotado pelo Novo Código, o qual prestigia o termo "tutela provisória", e busca, a partir dele, dar tratamento harmônico e sistemático para a tutela cautelar e para a tutela satisfativa de urgência e da evidência. Pretende-se, desse modo, oferecer uma reflexão a respeito do modo como os referidos temas são tratados pelo Novo Código de Processo Civil.

\footnotetext{
${ }^{1}$ Artigo recebido em 28/04/15 e aprovado em 12/06/2015.
} 
Revista Eletrônica de Direito Processual - REDP. Volume 15. Janeiro a Junho de 2015 Periódico Semestral da Pós-Graduação Stricto Sensu em Direito Processual da UERJ. Patrono: José Carlos Barbosa Moreira. www.redp.com.br ISSN 1982-7636 PP 268-298

PALAVRAS-CHAVE: Tutela provisória. Tutelas de urgência. Tutela antecipada.

RIASSUNTO: Questo saggio si propone di esaminare il tema della "tutela provvisoria" prevista nel libro V della Parte Generale del nuovo Codice di Processo Civile come genere di cui sono specie la tutela cautelare, la tutela antecipata e la tutela della evidenza. L'obiettivo è quello di chiarire il quadro concettuale adottato dal Nuovo Codice, che onora il termine "tutela provvisoria" e mira, da esso, a dare tratamento armonico e sistematico per la tutela cautelare e la tutela satisfativa di urgenza e di evidenza. Si vuole, dunque, offrire una riflessione su come questi temi vengono trattati dal Nuovo Codice di Processo civile.

PAROLE CHIAVE: Tutela provvisoria. Tutela cautelare. Tutela antecipata.

SUMÁRIO: 1 Tutela provisória e sua sistematização no Novo CPC; 2 Tutela provisória e tutela definitiva; 3 Tutela provisória e tutela sumária; 4 Tutela provisória de urgência; 4.1 Aspectos conceituais: tutela cautelar e tutela satisfativa; 4.2 Requisitos para a concessão da tutela provisória de urgência; 4.2.1 Perigo de dano ou risco ao resultado útil do processo; 4.2.2 Elementos que evidenciem a probabilidade do direito; 5 Tutela antecipada antecedente e estabilização da tutela antecipada; Considerações finais; Referências Bibliográficas.

\section{Tutela provisória e sua sistematização no Novo CPC}

O Código de Processo Civil de 1973 não contava com uma sistematização do tema correspondente à "tutela provisória". O esquema conceitual construído pela doutrina brasileira a respeito do tema, por outro lado, tinha como ponto de partida o plano do direito material, em que se distinguia o direito à tutela satisfativa e o direito à tutela cautelar. Essas duas espécies de tutela jurisdicional do direito eram trabalhadas dentro de uma classe maior, no caso, a classe das tutelas de urgência. Foi a partir desse quadro que, gradualmente, foram sendo corrigidos equívocos presentes no Código Buzaid. 
Revista Eletrônica de Direito Processual - REDP. Volume 15. Janeiro a Junho de 2015 Periódico Semestral da Pós-Graduação Stricto Sensu em Direito Processual da UERJ. Patrono: José Carlos Barbosa Moreira. www.redp.com.br ISSN 1982-7636 PP 268-298

Primeiramente, foi sendo abandonada a ideia de que o processo cautelar guardasse correspondência com a chamada tutela cautelar ${ }^{2}$, na medida em que, dentro do Livro III do Código, em que estava previsto o chamado "processo cautelar" também eram encontradas hipóteses de tutelas satisfativas de urgência, como era o caso dos alimentos provisionais, isso sem falar no uso desenfreado das cautelares inominadas satisfativas, anomalia surgida na prática em face da ausência de uma técnica que permitisse a obtenção da tutela jurisdicional satisfativa diante de situações de urgência ${ }^{3}$.

Em 1994, com a inserção do instituto da antecipação da tutela no livro I do Código de 1973, buscou-se distinguir e separar a tutela cautelar da tutela satisfativa conferida em caráter provisório, sendo possível afirmar que os provimentos que não tinham natureza definitiva encontravam-se espalhados pelo Código sem nenhuma sistematização. O que ocorreu, a partir daquele momento, foi uma separação mais precisa entre a tutela cautelar e a tutela satisfativa de urgência, que poderia ser conferida em caráter antecipado no bojo do processo de conhecimento, com caráter atípico. Não que antes de 1994 não existissem possibilidades de antecipação da tutela satisfativa, porém isso era reservado às liminares previstas nos procedimentos especiais do Livro IV do CPC/73 e da legislação extravagante. Ainda, a tutela antecipada prevista no art. 273 do CPC/73 admitia a sua concessão tanto diante do perigo na demora, quanto diante da evidência do direito, sendo que esta última não se enquadrava adequadamente dentro do gênero tutela de urgência.

O Novo Código apresenta uma nítida tentativa de conferir tratamento harmônico à tutela provisória, tanto que dela veio a tratar com exclusividade no livro $\mathrm{V}$ da sua Parte Geral. O esquema conceitual criado pelo Novo Código tem em seu centro a categoria "tutela provisória", que se apresenta como um contraponto à tutela definitiva (tutela de cognição exauriente) $)^{4}$. $\mathrm{O}$ conceito de tutela provisória não tem nenhuma relação com o conteúdo material do provimento jurisdicional - vale dizer, com o fato

\footnotetext{
${ }^{2}$ O processo cautelar é somente o instrumento pelo qual, no Código de 1973, pode-se obter a tutela cautelar, razão pela qual tutela cautelar e processo cautelar não podem ser encarados como sinônimos (SILVA, Ovídio A. Baptista da. Curso de processo civil. v.2. Processo cautelar (tutelas de urgência) 4. ed., rev. atual. Rio de Janeiro: Forense, 2007-2008, p. 3).

${ }^{3}$ Trata-se do fenômeno da rebelião da prática contra o processo civil, de que fala Marinoni. A respeito, ver MARINONI, Luiz Guilherme. Técnica processual e tutela dos direitos. São Paulo: Revista dos Tribunais, 2004, pp. 81-97. SILVA, Ovídio A. Baptista da. Curso de processo civil. v.2. Processo cautelar (tutelas de urgência) 4. ed., rev. atual. Rio de Janeiro: Forense, 2007-2008, p. 9-23.

${ }^{4} \mathrm{O}$ conceito de tutela definitiva adotado, no ponto, pelo Código, tem natureza processual, traduzindo-se no grau de cognição e no consequente grau de estabilidade da decisão. Não está atrelado à tutela conferida no plano do direito material.
} 
Revista Eletrônica de Direito Processual - REDP. Volume 15. Janeiro a Junho de 2015 Periódico Semestral da Pós-Graduação Stricto Sensu em Direito Processual da UERJ. Patrono: José Carlos Barbosa Moreira. www.redp.com.br ISSN 1982-7636 PP 268-298

dele ser satisfativo ou cautelar -, mas, sim, com a característica de não ser proferido com base em cognição exauriente e, por conseguinte, ter aptidão para ser a qualquer tempo revogado ou modificado, conforme preceitua textualmente o artigo 296 do Novo Código ${ }^{5}$.

Dentro do gênero "tutela provisória" inserem-se, conforme o Novo CPC, duas espécies que se diferenciam pelo fundamento para a sua concessão, e não pelo seu conteúdo, quais sejam: a tutela de urgência e a tutela da evidência ${ }^{6}$. A primeira espécie divide-se em tutela cautelar e tutela antecipada, ao passo que a segunda não possui subespécies, mas apenas diferentes pressupostos para a sua concessão. Ainda, a tutela de urgência (cautelar ou antecipada) subdivide-se, conforme o momento da sua concessão, em antecedente ou incidente ${ }^{7}$.

Há, nessa classificação, um grave equívoco que compromete bastante a pretensão de sistematização da matéria. É que a tutela cautelar contrapõe-se à tutela satisfativa, e não à tutela antecipada. Tutela cautelar e tutela satisfativa são conceitos que concernem à tutela do direito material, na medida em que, respectivamente, dizem respeito à proteção do direito (cautela) e à realização do direito (satisfação). A antecipação da tutela, nos moldes em que construída e aperfeiçoada pela doutrina sob a égide do Código de 1973, era uma técnica processual destinada à concessão de um provimento provisório, capaz de conferir, antes do final do processo a tutela satisfativa ou até mesmo a tutela cautelar pretendida pelo autor (tome-se, como exemplo, as liminares do processo cautelar, que permitiam a antecipação da tutela cautelar ${ }^{8}$, tendo como pressuposto tanto a urgência quanto a evidência do direito afirmado.

\footnotetext{
${ }^{5}$ Art. 296. A tutela provisória conserva sua eficácia na pendência do processo, mas pode, a qualquer tempo, ser revogada ou modificada.

${ }^{6}$ A expressão "tutela da evidência" remonta à possibilidade de concessão da tutela jurisdicional, com caráter satisfativo e de modo provisório, tendo por base não ainda a certeza do direito, mas a sua evidência. Trata-se de mecanismo que, no direito francês, tem respaldo no référé provision, sob a base do qual se admite que um credor cuja obrigação não seja seriamente contestada possa obter ante causam ou no curso da causa, mediante tutela sumária de référé um provimento antecipatório de condenação (JOMMI, Alessandro. Il référé provision: ordinamento francese ed evoluzione della tutela sommaria anticipatoria in Itália. Torino: G. Giappichelli, 2005, p. 2. Na doutrina nacional, para uma ampla análise do référé francês consultar, indispensavelmente, PAIM, Gustavo Bohrer. O référé francês. Revista de Processo, São Paulo, v. 37, n. 203, p. 99-118, jan. 2012).

${ }^{7}$ Isso fica bem claro tanto no art. 294 que abre o Livro V do Novo CPC, quanto na sua divisão em três títulos (título I - Disposições gerais; Título II - Da Tutela da urgência; Título III - Da tutela da evidência). A propósito, dispõem o art. 294 e seu respectivo parágrafo: Art. 294. A tutela provisória pode fundamentar-se em urgência ou evidência. Parágrafo único. A tutela provisória de urgência, cautelar ou antecipada, pode ser concedida em caráter antecedente ou incidental.

${ }^{8}$ Sobre a necessidade de distinguir a antecipação que se realiza na tutela cautelar daquela que se atua no âmbito dos chamados acertamentos com prevalente função executiva, ver TOMMASEO, Ferruccio. I provvedimenti d'urgenza: struttura e limiti della tutela antecipatoria. Padova: CEDAM, 1983, p. 36. Na
} 
Revista Eletrônica de Direito Processual - REDP. Volume 15. Janeiro a Junho de 2015 Periódico Semestral da Pós-Graduação Stricto Sensu em Direito Processual da UERJ. Patrono: José Carlos Barbosa Moreira. www.redp.com.br ISSN 1982-7636 PP 268-298

Desse modo, a única maneira possível de compreender a sistematização oferecida pelo Novo CPC no tocante à tutela provisória é ler, quando o Código fala em tutela antecipada, a expressão "tutela satisfativa fundada na urgência", a qual se apresenta, no que diz respeito à sua finalidade, como um contraponto à tutela cautelar, a qual também é fundada na urgência. A chamada "tutela da evidência" também é uma tutela satisfativa que, no entanto, não se fundamenta na urgência. Então, pode-se concluir que (i) o Novo CPC optou por dar ênfase ao termo "tutela provisória" o qual não guarda relação alguma com a finalidade do provimento jurisdicional, mas tãosomente com a possível revogação, modificação ou confirmação do provimento dentro do mesmo processo; (ii) a divisão da tutela provisória em tutela de urgência e de evidência tem unicamente como critério de distinção os pressupostos - urgência ou evidência - que fundamentam essas duas espécies de tutela provisória; (iii) a tutela provisória de urgência poderá, no que diz respeito ao seu conteúdo material, ser cautelar ou satisfativa - sendo que esta última o Código denomina de "tutela antecipada" -, ao passo que a tutela provisória de evidência será sempre satisfativa.

Feitas essas breves observações sobre a sistematização da "tutela provisória" no Novo CPC, cumpre verificar, com maior atenção, os principais conceitos chaves que permeiam o tema.

\footnotetext{
doutrina brasileira, reconhecendo que a técnica antecipatória é meio para a obtenção antecipada tanto da tutela cautelar quanto da tutela satisfativa, ver MITIDIERO, Daniel. Antecipação da tutela: da tutela cautelar à técnica antecipatória. São Paulo: Revista dos Tribunais, 2013. Sobre o ponto, é importante registrar que a doutrina nem sempre é muito clara na diferenciação entre técnica antecipatória e tutela antecipada, embora dela se utilize. Veja-se, nesse sentido, o caso de Luiz Guilherme Marinoni, autor que no Brasil, talvez seja o nome mais importante e inovador no tocante ao tema da técnica processual. Em diversos momentos da sua vasta obra, Marinoni fala de uma "técnica da tutela antecipatória" (MARINONI, Luiz Guilherme. Tutela antecipada e julgamento antecipado: parte incontroversa da demanda. $5^{\text {a }}$ ed. rev, atual. e ampl. São Paulo: Revista dos Tribunais, 2002, pp. 37-39) No entanto, o próprio autor explica que o "direito à técnica antecipatória quer dizer direito à possibilidade de requerimento e de obtenção da antecipação da tutela" de modo que "o direito à técnica antecipatória é o direito à técnica processual capaz de viabilizar a antecipação da tutela". Ainda, afirma que "o direito à tutela antecipatória não é apenas o direito à obtenção de decisão concessiva de tutela antecipatória, mas sim o direito ao bem da vida outorgado por essa decisão. Ou seja, pensar em direito à tutela antecipatória implica falar na sua plena e integral efetivação" (MARINONI, Luiz Guilherme. Técnica processual e tutela dos direitos. São Paulo: Revista dos Tribunais, 2004, p. 200). Já na sua mais importante sobre o tema, Marinoni utiliza, em diversos momentos, o termo "técnica antecipatória" (MARINONI, Luiz Guilherme. Antecipação da tutela. $11^{\mathrm{a}}$ ed. rev., e atual. São Paulo: Revista dos Tribunais, 2009, p. 43 e seguintes). No presente ensaio, a afirmação de que a "antecipação da tutela" era vista como uma técnica processual parte de uma tomada de posição segundo a qual antecipar a tutela nada diz acerca do conteúdo que é antecipado, vale dizer, da tutela que é antecipada. Desse modo, seria possível utilizá-lo sempre que o provimento provisório consiste na antecipação da tutela satisfativa ou mesmo cautelar. Como o Novo Código restringe o termo "tutela antecipada" às situações de tutela satisfativa de urgência, o termo "técnica antecipatória" parece ser, hoje, o mais adequado para exprimir tanto o fenômeno da antecipação da tutela satisfativa (de urgência e de evidência), quanto o da tutela cautelar.
} 
Revista Eletrônica de Direito Processual - REDP. Volume 15. Janeiro a Junho de 2015

Periódico Semestral da Pós-Graduação Stricto Sensu em Direito Processual da UERJ.

Patrono: José Carlos Barbosa Moreira. www.redp.com.br ISSN 1982-7636 PP 268-298

\section{Tutela provisória e tutela definitiva}

O conceito de provisoriedade, nos termos em que é utilizado no processo civil, é essencialmente ambíguo ${ }^{9}$. O esclarecimento dessa ambiguidade mostra-se essencial para a compreensão da tutela provisória prevista no Novo CPC. Para o Código, a tutela provisória tem caráter eminentemente normativo. Significa dizer que a expressão tutela provisória não diz respeito necessariamente aos possiveis efeitos fáticos porventura causados pela decisão jurisdicional. Provisório, para o Novo CPC, é o ato jurisdicional. Daí que a provisoriedade deverá ser pensada como característica do provimento jurisdicional, que poderá ser revogado, modificado ou confirmado por uma decisão posterior, esta, sim, definitiva. O provimento provisório constitui uma versão não definitiva do provimento final.

A contraposição entre provisório e definitivo - que, repita-se, pode ser visualizada tanto no plano normativo quanto no plano fático ${ }^{10}$ - é bastante conhecida no direito brasileiro a partir da clássica lição de Lopes da Costa. Para ele, a barraca onde o desbravador do sertão acampa, até melhor habitação, é provisória, na medida em que irá perdurar até que seja trocada pela habitação definitiva ${ }^{11}$. Vale dizer, provisório é aquilo que perdura até ser substituído pelo definitivo ${ }^{12}$.

\footnotetext{
${ }^{9}$ SILVA, Ovídio A. Baptista da. Curso de processo civil. v.2. Processo cautelar (tutelas de urgência) 4. ed., rev. atual. Rio de Janeiro: Forense, 2007-2008, p. 29.

${ }^{10}$ Nesse sentido, Ferruccio Tommaseo: "mi sembra opportuno notare che la provvisorietà della tutela può essere valutata sotto due diversi, anche se concorrenti profili. Da un lato, infatti, bisogna riferirsi alla durata nel tempo del provvedimento, durata che dipende dalle regole processuali sui rapporti fra misura urgente e sentenza di merito; dall'altro lato - ed è un tratto particolarmente importante - la provvisorietà può essere determinata da una serie di valutazioni sulla natura degli effetti scaturienti dal provedimento urgente" (TOMMASEO, Ferruccio. I provvedimenti d'urgenza: struttura e limiti della tutela antecipatoria. Padova: CEDAM, 1983, p. 150).

${ }^{11}$ LOPES DA COSTA, Alfredo Araújo. Medidas preventivas: medidas preparatórias - medidas de conservação. 3a ed., São Paulo: Sugestões Literárias, 1966, pp. 15-16

12 Calamandrei, embora, equivocadamente, atrele o conceito de provisoriedade aos provimentos cautelares, seja quanto à eficácia normativa do provimento, seja quanto aos efeitos fáticos, também adota o conceito de provisoriedade como contraposto ao definitivo, na medida em que afirma que a provisoriedade dos provimentos cautelares seria portanto um aspecto e uma consequência de uma relação que passa entre os efeitos do provimento antecedente (cautelar) e aqueles do provimento subsequente (definitivo), com o qual ocorreria a cessação dos efeitos do primeiro (CALAMANDREI, Piero. Introduzione allo studio sistematico dei provvedimenti cautelari. Paodva: CEDAM, 1936, p. 11). Na verdade, entre o provimento cautelar, que versa sobre o direito à cautela, e o provimento definitivo que versa sobre o próprio direito acautelado, não há uma identidade qualitativa, pois seus efeitos não guardam identidade, razão pela qual, do ponto de vista fático, não há como considerar que a tutela cautelar seja provisória, sobrevindo até que seja substituída pela tutela jurisdicional definitiva. Conforme Ovídio Baptista da Silva, arresto concedido no curso de uma ação condenatória não terá absolutamente nada a ver com a lide satisfativa, a que o arresto se "refere"; e nem será tutela que antecipe algum efeito da sentença de condenação. As questões litigiosas porventura controvertidas na ação de arresto não se confundem com as questões da ação principal. Isto que para nós apresenta-se como óbvio pode parecer, quem sabe, uma heresia para o bom carneluttiano, ou até mesmo para um discípulo fiel de CALAMANDREI
} 
Revista Eletrônica de Direito Processual - REDP. Volume 15. Janeiro a Junho de 2015 Periódico Semestral da Pós-Graduação Stricto Sensu em Direito Processual da UERJ. Patrono: José Carlos Barbosa Moreira. www.redp.com.br ISSN 1982-7636 PP 268-298

Então, quando o Novo CPC fala em tutela provisória, faz referência ao provimento jurisdicional que, assegurando ou satisfazendo o direito do autor (tutela cautelar ou tutela satisfativa), poderá ser revertido. Isso não significa que os efeitos da decisão necessariamente sejam provisórios. Em que pese muitas vezes o sejam, isso não constitui uma regra. É o caso da decisão provisória que concede antes do final do processo a satisfação do direito aos alimentos, como bem exemplificava Ovídio Baptista da Silva. O que é provisório, nos alimentos comumente chamados de provisionais, não são os alimentos concedidos e pagos a cada prestação pelo devedor, mas o provimento jurisdicional que os concede. Os alimentos, no plano fático, uma vez percebidos pelo suposto credor serão definitivos, embora a decisão que os concede esteja sujeita à revogação ${ }^{13}$. Acertada, nessa senda, a lição de Cécile Chainais, para quem o fato de a decisão ser provisória não faz com que os seus efeitos não tenham aptidão para se tornarem definitivos, assim como a aptidão de os efeitos de uma decisão tornarem-se definitivos não retira o caráter provisório da decisão que os produziu ${ }^{14}$.

Desse modo, o Novo CPC trabalha com um conceito de tutela provisória estritamente normativo, em contraposição à tutela definitiva, que corresponderia à tutela jurisdicional que não admite revisão ou modificação pelo mesmo juízo que a concedeu. Assim, pode-se dizer que a tutela concedida provisoriamente é a mesma que poderia ser concedida de modo definitivo. A diferença entre elas está no fato de a tutela provisória ser menos estável, pois há uma potencialidade de revisão que lhe é inerente.

\section{Tutela provisória e tutela sumária}

A tutela provisória caracteriza-se pela sua ausência de definitividade. Isso decorre da amplitude da cognição judicial dispensada para o provimento que concede a tutela provisória. Pode-se dizer que, em regra, o procedimento comum e, consequentemente, a definitividade da decisão jurisdicional, pressupõe tanto máxima amplitude quanto às matérias que nele podem ser discutidas, impedindo-se, desse modo,

(SILVA, Ovídio A. Baptista da. Curso de processo civil. v.2. Processo cautelar (tutelas de urgência) 4. ed., rev. atual. Rio de Janeiro: Forense, 2007-2008, p. 55).

${ }^{13}$ SILVA, Ovídio A. Baptista da. Curso de processo civil. v.2. Processo cautelar (tutelas de urgência) 4. ed., rev. atual. Rio de Janeiro: Forense, 2007-2008, p. 59.

${ }^{14}$ CHAINAIS, Cécile. La protection juridictionnelle provisoire dans le procès civil en droit français et italien. Paris: Dalloz, 2007, p. 223. Há, no ponto, uma nítida cisão entre eficácia e efeitos do provimento jurisdicional, o que, no direito brasileiro, foi bem apreendido por Barbosa Moreira quando do estudo da coisa julgada. A respeito, ver BARBOSA MOREIRA, José Carlos. Eficácia da sentença e autoridade da coisa julgada. In: Temas de direito processual: terceira série. São Paulo: Saraiva, 1984, pp. 100-101. 
Revista Eletrônica de Direito Processual - REDP. Volume 15. Janeiro a Junho de 2015 Periódico Semestral da Pós-Graduação Stricto Sensu em Direito Processual da UERJ. Patrono: José Carlos Barbosa Moreira. www.redp.com.br ISSN 1982-7636 PP 268-298 que determinadas questões sejam pré-excluídas do conhecimento do juiz ${ }^{15}$, quanto à profundidade com que o juiz conhece tais matérias, vedando-se, por conseguinte, que a decisão da causa seja baseada em juízos de mera probabilidade ${ }^{16}$.

No direito brasileiro, costuma-se dividir a cognição judicial em dois planos. Fala-se em plano horizontal da cognição para tratar das matérias que podem ser conhecidas pelo juiz no processo. Com efeito, no que concerne ao plano horizontal da cognição, o procedimento comum é caracterizado por uma cognição plena, ou seja, cognição sem limitação acerca dos fundamentos e defesas pertinentes à situação de direito material deduzida. Aqui se está, pois, diante da extensão da cognição. Por outro lado, a cognição pode ser surpreendida também no plano vertical, referindo-se, então, à profundidade com que o juiz pode conhecer as matérias referentes ao processo, hipótese na qual o procedimento comum vale-se da cognição exauriente ${ }^{17}$.

A definição conceitual do tema cobra precisão técnica, tarefa que, na doutrina brasileira, foi cumprida com perfeição por Ovídio A. Baptista da Silva ${ }^{18}$. Nessa senda, com base nas lições de Chiovenda, pode-se contrapor a cognição plena à "cognição incompleta porque parcial" e a cognição exauriente à "cognição incompleta porque superficial" 19 . Com efeito, a cognição no plano horizontal pode sofrer um corte vertical (sumarização vertical), vedando-se ao juiz “conhecer de toda uma parcela de questões litigiosas que, não fosse uma determinação do direito material, poderiam ser suscitadas

\footnotetext{
${ }^{15}$ Conforme Víctor Fairén Guillén, “o juízo ordinário, se baseia e tem baseado sempre no desejo de acabar para sempre com o litígio entre as partes de maneira judicial, de tal modo que não seja possível um novo processo sobre o ponto resolvido (a exceção dos remédios extraordinários de revisão). Por isso é de desejar na maior extensão e desenvolvimento das pretensões, de tal modo que todas as relações litigiosas sejam resolvidas. Por isso se permite às partes completar do melhor modo possível seus sistemas de defesas; por isso são amplos os meios de impugnação e os prazos que lhes fazem acessíveis; por isso se dá a eleger às partes entre toda as diversidades de meios de prova. O conjunto, justifica uma copiosa série de formalismos, preclusões, providências jurisdicionais, etc" (FAIREN GUILLEN, Victor. El juicio ordinario y los plenarios rapidos (los defectos en la recepcion del derecho procesal comun; sus causas y consecuencias en doctrina y legislacion actuales). Barcelona: Bosch, 1953, p. 53).

${ }^{16}$ Sobre o tema, ver a crítica formulada por Ovídio A. Baptista da Silva acerca da expressão "ampla defesa", utilizada pelo constituinte, conferido ao processo civil o mesmo tratamento conferido ao processo penal quanto à chamada "plenitude de defesa", em SILVA, Ovídio A. Baptista da. A "plenitude de defesa" no processo civil. In: Da sentença liminar à nulidade da sentença. Rio de Janeiro: Forense, 2002.

${ }^{17}$ A distinção da cognição em dois planos (horizontal e vertical) deve sua sistematização à obra de Kazuo Watanabe (WATANABE, Kazuo. Da cognição no processo civil. 2. ed. Campinas: Bookseller, 2000).

${ }^{18}$ A obra de Ovídio é vasta no que diz respeito ao tema. A respeito, SILVA, Ovídio A. Baptista da. Procedimentos especiais. Rio de Janeiro: Aidê, 1989, p. 46. SILVA, Ovídio A. Baptista da. O contraditório nas ações sumárias. Revista da Ajuris. Ano XXVI. n. 80. Porto Alegre: Ajuris, 2000. SILVA, Ovídio A. Baptista da. Do processo cautelar. Rio de Janeiro: Forense, 1996.

${ }^{19}$ CHIOVENDA, Giuseppe. Azioni sommarie: la sentenze di condanna con riserva. In: CHIOVENDA, Giuseppe. Saggi di diritto processuale civile (1900-1930). v 2. Roma: Foro Italiano, 1930-1931. p. 122.
} 
Revista Eletrônica de Direito Processual - REDP. Volume 15. Janeiro a Junho de 2015 Periódico Semestral da Pós-Graduação Stricto Sensu em Direito Processual da UERJ. Patrono: José Carlos Barbosa Moreira. www.redp.com.br ISSN 1982-7636 PP 268-298 pelo demandado"20. Trata-se de uma sumariedade material, o que significa dizer que a limitação da cognição abarca o plano do direito material, não se tratando de uma mera sumariedade procedimental. É o exemplo corriqueiro das ações possessórias, nas quais o conhecimento do juiz fica limitado à posse, sendo-lhe vedada a análise de questões relativas à propriedade ${ }^{21}$. Por outro lado, fala-se em cognição incompleta porque superficial em todas as situações nas quais é dado ao juiz decidir com base em juízo de probabilidade, sem exaurir todas as possibilidades de conhecimento da matéria em apreço. Aqui, há um corte horizontal (sumarização horizontal) no plano vertical da cognição, tal como nos interditos pretorianos do direito romano e nas liminares do direito contemporâneo.

Interessa aqui, principalmente, o âmbito vertical da cognição, vale dizer, a questão envolvendo a profundidade com que o juiz analisa os elementos necessários para proferir uma decisão sobre o mérito da causa. A cognição quando não exauriente será sumária. Normalmente, se diz sumária a cognição fundada em juízo de probabilidade acerca do direito afirmado pelo autor. É o caso das tutelas antecipada e cautelar, nas quais se basta, para a formação da decisão, a probabilidade do direito afirmado pelo autor ${ }^{22}$. No entanto, também a tutela da evidência é fundada em cognição

\footnotetext{
${ }^{20}$ SILVA, Ovídio A. Baptista da. O contraditório nas ações sumárias. Revista da Ajuris. Ano XXVI. n. 80. Porto Alegre: Ajuris, 2000, p. 213. Conforme o doutrinador gaúcho, "nestes casos, haverá o que a doutrina passou a denominar 'cognição exauriente', porém aqui, essa exaustão cognitiva sobre as questões litigiosas, cujo exame lhe fora permitido, pode ser limitadíssima, como ocorre, por exemplo, na ação de anulação de títulos ao portador" (Idem. Ibidem). Interessante notar que Ovídio A. Baptista da Silva diverge sensivelmente de Kazuo Watanabe, na medida em que, para o autor gaúcho, haverá sumarização da demanda tanto no plano da horizontalidade, quanto da verticalidade.

${ }^{21}$ Essa sumariedade da cognição no tocante ao plano horizontal, com exclusão de certas matérias da mesma causa, costuma estar presente em alguns procedimentos especiais, o que levou a doutrina a utilizar a terminologia tutelas jurisdicionais diferenciadas, cuja nota distintiva estaria justamente na sumariedade da cognição. Nesse sentido, LEONEL, Ricardo de Barros. Tutela jurisdicional diferenciada. São Paulo: RT, 2010. WAMBIER, Luiz Rodrigues; ALVIM, Teresa Celina Arruda. Tutela diferenciada. Revista de Processo, São Paulo, v.35, n.180, fev. São Paulo: Revista dos Tribunais, 2010. É importante registrar que a expressão tutelas jurisdicionais diferenciadas é tributada a Andrea Proto Pisani, para quem o termo é equívoco. Para ele, uma coisa é a tutela jurisdicional diferenciada como a predisposição de mais procedimentos de cognição plena e exauriente alguns dos quais modelados sob peculiaridades de determinadas situações de direito material; outra coisa é a tutela jurisdicional diferenciada como a predisposição de formas típicas de tutela sumária, seja de natureza cautelar, seja de natureza satisfativa (PROTO PISANI, Andrea. Sulla tutela giurisdizionale differenziata. Rivista di diritto processuale, n. 4, Padova: Cedam, 1979, pp. 537-538). Em ensaio publicado em 2006, Pisani assume sua culpa por não ter, na década de 70, evidenciado com o máximo de clareza a diferença - o fosso como diz ele - que se coloca entre os ritos especiais de cognição plena e os processos sumários não cautelares. Na verdade, o que Pisani pretende atacar é a proliferação de procedimentos especiais de cognição plena, os quais, para ele, cresceram muito em razão da lentidão do procedimento ordinário (PROTO PISANI, Andrea. Dai riti speciali ala differenziazione del rito ordinario. Il foro italiano. Roma: Il foro italiano, 2006, p. 86).

${ }^{22}$ Importante advertir que, na tutela cautelar, a sumariedade do ponto de vista material diz respeito à situação cautelanda, ou seja, ao direito que se objetiva assegurar. O direito à cautela do direito (pretensão à segurança) será analisado com base em cognição exauriente, razão pela qual é correto dizer que haverá
} 
Revista Eletrônica de Direito Processual - REDP. Volume 15. Janeiro a Junho de 2015 Periódico Semestral da Pós-Graduação Stricto Sensu em Direito Processual da UERJ. Patrono: José Carlos Barbosa Moreira. www.redp.com.br ISSN 1982-7636 PP 268-298 sumária, na medida em que também pressupõe cognição não exauriente, seja sobre a questão controversa, seja sobre parcela dela ${ }^{23}$. O direito afirmado pelo autor, no entanto, apresentar-se-á mais que provável, uma vez que evidente ${ }^{24}$.

O que deve ficar assentado é que a ausência de cognição exauriente é o elemento central da tutela provisória. Caso fosse fundada em cognição exauriente, a tutela não seria provisória, mas definitiva.

\section{Tutela provisória de urgência}

\subsection{Aspectos conceituais: tutela cautelar e tutela satisfativa}

O Novo CPC reserva um capítulo específico para as disposições gerais da tutela provisória de urgência. Cabe aqui enfatizar que a urgência é fundamento para a tutela provisória, a qual, nos termos do Código, poderá ser cautelar ou antecipada (na verdade, satisfativa). Dito de outro modo, em situações nas quais a urgência - ou melhor, o tempo - se apresenta como um risco ao direito afirmado pelo autor, o processo reserva uma tutela provisória cujo objetivo é neutralizá-lo, seja assegurando a futura satisfação do direito referido pelo autor, seja satisfazendo-o antes do final do processo.

formação de coisa julgada material quanto ao direito à cautela, mas não quanto ao direito acautelado, pois este não é analisado com base em cognição exauriente quando concedida a cautelar. Sobre o tema, ver COSTA, Eduardo José da Fonseca. Sentença cautelar, cognição e coisa julgada: reflexões em homenagem à memória de Ovídio Baptista. Revista de Processo, São Paulo, v. 36, n. 191, p. 357-376, jan. 2011.

${ }^{23} \mathrm{E}$ que, no caso, poderá haver reserva de cognição quanto às exceções substanciais alegadas pelo réu, na medida em que serão analisadas com a devida profundidade após ter sido concedida a tutela provisória. É interessante notar que, analisando o art. 273, II, do CPC/73, Andrea Proto Pisani nele visualizava uma técnica geral para a reserva da cognição acerca das exceções substanciais. Para ele, no processo de cognição plena, o tempo de desenvolvimento do processo pode derivar da necessidade probatória tanto dos fatos constitutivos, quanto dos fatos alegados pelo réu. Dessa forma, uma vez obtida a prova dos fatos constitutivos, seria possível consentir com a emanação de um provimento de condenação com base na prova plena dos fatos constitutivos, mas, porém, com a inexistência, ao menos em nível de cognição sumária, dos fatos impeditivos, modificativos e extintivos alegados pelo réu. Nesses casos, sustenta a necessidade de que seja emanado um provimento pelo qual o autor venha imediatamente munido de um título executivo, de formação judicial, com o qual poderá colocar em movimento um procedimento de execução forçada, restando ao devedor a possibilidade de continuar a dar impulso ao processo pela cognição dos fatos alegados como fundamento da defesa (PROTO PISANI, Andrea. La tutela sommaria in generale e il procedimento per ingiuzione nell'ordinamento italiano. Revista de processo. n. 90. Ano 23. Abril-Junho de 1998, p. 27).

${ }^{24}$ No sentido de que "a evidência do direito para fins de antecipação da tutela é aferida mediante cognição sumária e não mediante cognição exauriente", ver MITIDIERO, Daniel. Antecipação da tutela: da tutela cautelar à técnica antecipatória. São Paulo: Revista dos Tribunais, 2013, p. 135. Em sentido contrário, entendendo que a tutela da evidência é fundada em cognição exauriente, ver FUX, Luiz. Tutela de segurança e tutela da evidência (fundamentos da tutela antecipada). São Paulo: Saraiva, 1996, p. 310. No entanto, o mesmo autor entende que a tutela da evidência versa sobre "situações em que se opera mais que o fumus boni juris, mas a probabilidade de certeza do direito alegado, aliada à injustificada demora que o processo ordinário carreará até a satisfação do interesse do demandante, com grave desprestígio para o Poder Judiciário, posto que injusta a espera determinada” (Idem. Ibidem, pp. 305-306). 
Revista Eletrônica de Direito Processual - REDP. Volume 15. Janeiro a Junho de 2015 Periódico Semestral da Pós-Graduação Stricto Sensu em Direito Processual da UERJ. Patrono: José Carlos Barbosa Moreira. www.redp.com.br ISSN 1982-7636 PP 268-298

O tempo é um componente essencial do processo $^{25}$. Sem ele a própria ideia de processo seria inconcebível. É, porém, seu grande inimigo, consoante já advertia Carnelutti $^{26}$. Com efeito, a duração do processo pode ser vista como um vício congênito dos principais modelos de procedimento com os quais se administra a justiça frente aos órgãos jurisdicionais de qualquer ordenamento estatal ${ }^{27}$.

Lidar com o problema do tempo no processo exige encará-lo em diferentes aspectos. É que o tempo, em primeiro lugar, afigura-se necessário para que o processo conceda segurança aos litigantes, garantindo-se, desse modo, o respeito ao devido processo legal. Nessa perspectiva, costuma-se diferenciar o chamado tempo fisiológico do tempo patológico do processo. O tempo fisiológico é aquele tempo normal e necessário para o desenvolvimento do processo, ao passo que o tempo patológico diz respeito à duração anormal, excessiva do processo ${ }^{28}$.

Com efeito, é possível que, durante o desenvolvimento do tempo normal do processo, sejam postos em acontecimentos atos ou fatos idôneos a obstar a frutuosidade prática da futura sentença; ou, ainda, é possível que o objeto do processo seja um direito cujo conteúdo não seja capaz de permanecer em um estado de insatisfação por todo o tempo necessário para a prolação da sentença de cognição plena e exauriente, o que importará num prejuízo irreparável ao autor ${ }^{29}$. A diferença entre as duas situações é que, na primeira, a urgência se dá por um evento imprevisto externo ao processo (anterior ou contemporâneo a ele) que poderá causar a infrutuosidade do direito afirmado pela parte autora, como, por exemplo, a dispersão dos bens do devedor ${ }^{30}$; na segunda, o próprio

\footnotetext{
${ }^{25}$ ANDOLINA, Italo. Il tempo e il processo. Revista de processo. Ano 34. n. 176. out./2009, p. 260.

${ }^{26}$ CARNELUTTI, Francesco. Diritto e processo Nápoles: Morano, 1958, p. 232.

${ }^{27}$ COMOGLIO, Luigi Paolo. Durata ragionevole del giudizio e forme alternative di tutela. Revista de processo. Ano 32. n. 151. Set/2007. p. 73.

${ }^{28}$ PROTO PISANI, Andrea. Lezioni di diritto processuale civile. Napoli: Jovene, 1999, pp. 631-633. No mesmo sentido, TUCCI, José Rogério Cruz e. Tempo e processo: uma análise empírica das repercussões do tempo na fenomenologia processual (civil e penal). São Paulo: Rev. dos Tribunais, 1997. Sobre as relações entre tempo e processo ver, igualmente, JOBIM, Marco Félix. O direito à duração razoável do processo: responsabilidade civil do Estado em decorrência da intempestividade processual. 2. ed. Porto Alegre: Liv. do Advogado, 2012.

29 PROTO PISANI, Andrea. La tutela sommaria in generale e il procedimento per ingiunzione nell'ordinamento italiano. Revista de processo. n. 90. Ano 23. Abril-Junho de 1998, p. 27.

${ }^{30}$ Como bem destaca Ovídio Baptista, o qual separa o periculum in mora (requisito para a tutela satisfativa de urgência) do periculum damnum irreparabile (requisito para a tutela cautelar), $\mathrm{O}$ periculum in mora poderá facilmente ser normado, para formar, por exemplo, a tutela possessória ou os procedimentos de tipo monitório ou injuncional, ao passo que o risco de dano iminente será sempre um evento imprevisto, decorrente de uma emergência circunstancial que a ordem jurídica tutela através das medidas cautelares que, como os interditos romanos de que elas provêm, correspondem a remédios jurisdicionais para os casos de insuficiência da tutela normativa (SILVA, Ovídio A. Baptista da. Curso de
} 
Revista Eletrônica de Direito Processual - REDP. Volume 15. Janeiro a Junho de 2015 Periódico Semestral da Pós-Graduação Stricto Sensu em Direito Processual da UERJ. Patrono: José Carlos Barbosa Moreira. www.redp.com.br ISSN 1982-7636 PP 268-298 direito, pela sua natureza ou pela situação concreta, não pode suportar o tempo do processo (que já existe ou ainda não foi iniciado). Porém, em ambas, o tempo é tomado como urgência.

Nas duas situações, em que o tempo está atrelado à urgência, seria impensável que o autor ficasse na dependência do tempo normal do processo, vale dizer, ao tempo necessário para que o juiz, com base em cognição exauriente, profira um provimento jurisdicional definitivo. Nesse aspecto, a tutela provisória apresenta-se como alternativa para neutralizar os efeitos do tempo, seja para acautelar (assegurar o direito afirmado pelo autor), seja para satisfazê-lo desde já, antes, pois, do final do processo. É diante dessas duas situações que devem ser pensadas a tutela cautelar e a tutela antecipada.

A tutela cautelar visa a proteger um direito - e não o processo - diante de uma situação em que o pretenso direito do autor encontra-se em estado de risco. O direito referido (a situação cautelanda) deverá ser demonstrado como mera aparência, como probabilidade. A tutela cautelar consistirá, pois, em alguma medida tendente a assegurar a frutuosidade do direito referido, mas nunca a satisfazê-lo. O que é satisfeito na tutela cautelar é o direito à cautela, o direito à segurança do direito, mas nunca o próprio direito protegido.

O Novo Código, acertadamente, consagra a tese que há um direito substancial à cautela. Isso é importante porque por muito tempo a doutrina brasileira ${ }^{31}$, inspirada em Calamandrei, entendeu que a tutela cautelar seria um instrumento do processo, e não do direito acautelado ${ }^{32}$. Calamandrei, nesse sentido, falava que a tutela cautelar era marcada pela ideia da dupla instrumentalidade, ou seja, a tutela cautelar era instrumental em relação ao processo (de conhecimento ou de execução), este de caráter instrumental

processo civil. v.2. Processo cautelar (tutelas de urgência) 4. ed., rev. atual. Rio de Janeiro: Forense, 2007-2008, p. 54).

${ }^{31}$ Dentre os principais autores que negam a existência de um direito substancial à cautela, enxergando a tutela cautelar como instrumento da atividade jurisdicional, pode-se mencionar os seguintes: LACERDA, Galeno Vellinho de. Comentários ao Código de Processo Civil: v.8, t.1 (arts. 796 a 812). 10. ed. Rio de Janeiro: Forense, 2007. THEODORO JÚNIOR, Humberto. Curso de direito processual civil: v.2. 49. ed. Rio de Janeiro: Forense, 2014.

32 Para Calamandrei os provimentos cautelares servem para proteger o processo, e não o direito substancial. Nesse sentido, afirma o mestre italiano que "nei provvedimenti cautelari, più che lo scopo di attuare il diritto, lo scopo immediato di assicurare la efficacia pratica del provvedimento definitivo che servirà a sua volta ad attuare il diritto (...) Se tutti i provvedimenti giurisdizionali sono uno strumento del diritto sostanziale che attraverso essi si attua, nei provvedimenti cautelari si riscontra una strumentalità qualificata, ossia elevata, per così dire, al quadrato: essi sono infatti, immanancabilmente, un mezzo predisposto per la miglior riuscitadel provvedimento definitivo, che a sua volta è un mezzo per l'attuazione del diritto; sono cioè, in relazione alla finalità ultima della funzione giurisdizionale, strumenti dello strumento (CALAMANDREI, Piero. Introduzione allo studio sistematico dei provvedimenti cautelari. Paodva: CEDAM, 1936, pp. 21-22). 
Revista Eletrônica de Direito Processual - REDP. Volume 15. Janeiro a Junho de 2015 Periódico Semestral da Pós-Graduação Stricto Sensu em Direito Processual da UERJ. Patrono: José Carlos Barbosa Moreira. www.redp.com.br ISSN 1982-7636 PP 268-298 em relação ao direito material ${ }^{33}$. Ovídio Baptista, seguido por notáveis processualistas brasileiros $^{34}$, foi quem inaugurou o debate sobre a existência de um direito substancial à cautela $^{35}$, afirmando que a tutela cautelar protegia o direito, e não o processo ${ }^{36}$. Esse entendimento está expresso no art. 305 do Novo CPC, na medida em que este exige, do autor, a exposição sumária do direito que se objetiva assegurar.

A tutela cautelar - do ponto de vista fático - nunca será provisória. O que há de provisório na tutela cautelar, nos moldes do Novo CPC, é o provimento que concede essa forma de tutela do direito. Trata-se de um ponto sobre o qual o Novo Código, sem dúvida, pecou por falta de clareza conceitual, na medida em que não distinguiu, conforme ressaltado anteriormente, a provisoriedade no plano normativo e no plano fático. A tutela cautelar, no plano fático, será sempre temporária ${ }^{37}$, porque irá durar enquanto subsistir a situação de perigo que lhe legitima. Voltando-se novamente à clássica lição de Lopes da Costa, pode-se exemplificar com a diferenciação que este

\footnotetext{
${ }^{33}$ Para Ovídio Baptista da Silva "a tutela cautelar, portanto, protege o direito, e não o processo, como muitos entendem. Então, a primeira exigência que se faz presente, quando se quer conceituar o que seja a tutela cautelar, é a de estabelecer, no caso concreto, qual o interesse jurídico ameaçado de dano iminente, a carecer de proteção cautelar" (SILVA, Ovídio A. Baptista da. Curso de processo civil. v.2. Processo cautelar (tutelas de urgência) 4. ed., rev. atual. Rio de Janeiro: Forense, 2007-2008, p. 37).

${ }^{34}$ Conforme Marinoni, "o direito de ação impõe o dever legislativo de instituição de técnica processual capaz de permitir a obtenção de tutela cautelar exatamente porque há direito, situado no plano do direito substancial, à tutela cautelar. O direito à tutela cautelar não advém do processo. A tutela cautelar não se destina a garantir a efetividade da ação e, por isto mesmo, não pode ser pensada como uma mera técnica processual necessária a lhe outorgar efetividade. O direito à tutela cautelar está situado no plano do direito material, assim como o direito às tutelas inibitórias e ressarcitória. $\mathrm{O}$ titular do direito à tutela do direito por exemplo, ressarcitória - também possui direito à tutela de segurança (cautelar) do direito à tutela do direito" (MARINONI, Luiz Guilherme. Processo cautelar. 2a ed. São Paulo: Revista dos Tribunais, 2010, p. 22-23).

${ }^{35}$ Isso significa que, no plano do direito material, à um direito à segurança do direito, ou, como falava Ovídio Baptista da Silva, uma pretensão à segurança do direito, e não do processo (SILVA, Ovídio A. Baptista da. Curso de processo civil. v.2. Processo cautelar (tutelas de urgência) 4. ed., rev. atual. Rio de Janeiro: Forense, 2007-2008, p. 39).

${ }^{36}$ Registre-se que, para Ovídio, a pretensão à segurança pode nascer, inclusive, antes da pretensão satisfativa. Nesse sentido: "de qualquer modo, é possível separar o direito subjetivo da respectiva exigibilidade (pretensão) que a ordem jurídica, em certas hipóteses, confere a alguém, sem que ele invoque um direito subjetivo. Claro que a situação oposta, de direitos subjetivos sem pretensões, é banal. Basta pensar nos direitos a termo e nos direitos cuja pretensão esteja prescrita. O Código Civil é claro: 'Art. 130. Ao titular do direito eventual, nos casos de condição suspensiva ou resolutiva, é permitido praticar os atos destinados a conservá-lo'. Cuida-se, naturalmente, das pretensões e ações cautelares. 'Art. 131. O termo inicial suspende o exercício, mas não a aquisição do direito'. São hipóteses indiscutíveis de direitos ainda "inexigíveis", direitos a que faltam pretensões. Temos o direito, porém não podemos exigir a respectiva satisfação, a não ser - atendidos os pressupostos - o poder de exigir segurança que garanta sua futura satisfação. Nestas hipóteses, a pretensão à segurança nasce antes da pretensão satisfativa" (SILVA, Ovídio A. Baptista da. Jurisdição, direito material e processo. Rio de Janeiro: Forense, 2008, p. 94)

${ }^{37}$ Os provimentos cautelares não deverão, conforme Ovídio A. Baptista da Silva, "ter sua duração determinada pela emanação de uma providência definitiva que as substitua, mas haverão de durar enquanto dure o estado perigoso, e não mais!" (SILVA, Ovídio A. Baptista da. Curso de processo civil. v.2. Processo cautelar (tutelas de urgência) 4. ed., rev. atual. Rio de Janeiro: Forense, 2007-2008, p. 55).
} 
Revista Eletrônica de Direito Processual - REDP. Volume 15. Janeiro a Junho de 2015 Periódico Semestral da Pós-Graduação Stricto Sensu em Direito Processual da UERJ. Patrono: José Carlos Barbosa Moreira. www.redp.com.br ISSN 1982-7636 PP 268-298

autor faz da barraca - provisória até ser substituída pela morada definitiva - em relação aos andaimes de uma construção. Estes são temporários, pois devem permanecer até que o trabalho exterior de construção seja ultimado. No entanto, são definitivos, no sentido de que nada virá a substituí-los.

Tome-se como exemplo o arresto, o qual tem cabimento, em linhas gerais, quando aquele que se diz credor demonstra a probabilidade da existência do seu direito de crédito e o risco objetivo e atual de que o referido direito possa não ser satisfeito em face da insuficiência de patrimônio, do qual o devedor está se desfazendo para frustrar a futura execução. No caso, os bens poderão ser arrestados, e o arresto será definitivo enquanto durar a situação de perigo, não vindo a ser substituído por outra medida de igual natureza. É possível que no curso do processo - ou até mesmo antes - o devedor demonstre que estava se desfazendo dos bens objeto do arresto, mas que tem vasto patrimônio e que não há risco algum de infrutuosidade do direito de crédito. Nessa hipótese, em que deixou de existir a situação de perigo ao direito, o arresto também deixará de existir, sem que nada, do ponto de vista fático, venha a substituí-lo. Se isso acontecer, a decisão que provisoriamente concedeu o arresto será substituída por outra, definitiva, que irá revogá-lo, assim como é possível que ao final do processo a decisão provisória que concedeu o arresto seja confirmada.

A satisfação é o elemento central para distinguir a tutela antecipada (terminologia adotada de modo equivocado pelo código) da tutela de simples segurança (cautelar) que constitui uma forma de proteção que ainda não satisfaz, mas apenas assegura a futura satisfação o direito afirmado pelo requerente ${ }^{38}$. Satisfazer um direito significa realizá-lo faticamente no plano das relações humanas ${ }^{39}$. Nisso, Ovídio Baptista da Silva sempre se apresentou em franco combate à doutrina brasileira majoritária, que, com raras exceções, entende(ia) que satisfazer o direito era declará-lo de modo definitivo $^{40}$. Talvez com receio de se contrapor a consideráveis setores da doutrina, o

\footnotetext{
${ }^{38}$ SILVA, Ovídio A. Baptista da. Do processo cautelar. Rio de Janeiro: Forense, 1996, p. 11.

${ }^{39}$ SILVA, Ovídio. A. Baptista da. Curso de processo civil: processo cautelar (tutela de urgência), volume 3. 2a ed. São Paulo: Revista dos Tribunais, 1998, p. 84.

40 Sobre o tema, a aguda crítica de Ovídio A. Baptista da Silva: "temos dito reiteradamente ser entendimento da doutrina em geral a ideia de que somente haverá decisão quando houver julgamento definitivo da lide. Se o magistrado limitar-se a ordenar, imagina-se que o resultado do ato volitivo seja o produto de algum estado hipnótico, dado que não haveria, aí, qualquer decisão (...) Satisfazer o direito, portanto, é declará-lo existente, em sentença idônea a produzir coisa julgada (SILVA, Ovídio A. Baptista da. Decisões interlocutórias e sentenças liminares. AJURIS: Revista da Associação dos Juízes do Rio Grande do Sul, Porto Alegre, v.18, n.51, mar. 1991, pp. 140-145). Acerca das origens da equiparação da
} 
Revista Eletrônica de Direito Processual - REDP. Volume 15. Janeiro a Junho de 2015 Periódico Semestral da Pós-Graduação Stricto Sensu em Direito Processual da UERJ. Patrono: José Carlos Barbosa Moreira. www.redp.com.br ISSN 1982-7636 PP 268-298

Novo CPC evitou tomar partindo quanto ao tema, tanto que, cometendo um erro gravíssimo, nominou a tutela satisfativa de tutela antecipada.

\subsection{Requisitos para a concessão da tutela provisória de urgência}

\subsubsection{Perigo de dano ou risco ao resultado útil do processo}

O Novo CPC buscou simplificar a questão envolvendo os requisitos para a tutela provisória de urgência, na medida em que há somente um dispositivo conceituando a urgência necessária tanto para a tutela antecipada quanto para a tutela cautelar, o que, no antigo Código, era feito em mais de um dispositivo, cada qual com pequenas modificações na sua redação (arts. 273, I, 461, §3. ${ }^{\circ}$, e 798).

No Novo CPC a urgência encontra-se traduzida na expressão perigo de dano ou risco ao resultado útil do processo (art. 300, NCPC). Com efeito, a urgência restou unificada tanto para a tutela cautelar quanto para a tutela antecipada, o que, de certo modo, é um equívoco que poderá obnubilar o correto entendimento acerca das diferenças entre cada uma dessas formas de tutela.

É que, bem esclarecidos os contornos conceituais da matéria, a urgência para a concessão da tutela antecipada encontra-se espelhada no perigo na demora. Trata-se, pois, do perigo inerente ao tempo do processo frente ao direito que se busca satisfazer, não se confundindo com o pressuposto temporal relativo à tutela cautelar. A confusão conceitual deriva da própria falta de cuidado acerca da distinção entre a satisfação antecipada e a forma de tutela outorgada contra o estado perigoso (tutela cautelar) que, sem implicar satisfação do direito protegido, visa somente a protegê-lo. Tal distinção, era, no entanto, feita com razoável clareza pelos juristas medievais, conforme adverte Ovídio Baptista da Silva, através do manejo de dois conceitos fundamentais de periculum in mora e periculum damnum irreparabile ${ }^{41}$.

atividade jurisdicional à mera declaração, ver SILVA, Ovídio A. Baptista da. Jurisdição e execução na tradição romano-canônica. 3. ed., rev. Rio de Janeiro: Forense, 2007.

${ }^{41}$ SILVA, Ovídio A. Baptista da. Curso de processo civil. v.2. Processo cautelar (tutelas de urgência) 4. ed., rev. atual. Rio de Janeiro: Forense, 2007-2008, pp. 42-49. É claro que, se diante de uma situação de perigo ao resultado útil do processo, ou, em outras palavras, de perigo de dano iminente, causado por uma situação imprevista, for concedida uma tutela provisória satisfativa, a situação de perigo restará neutralizada pela imediata satisfação do direito. Tome-se como exemplo o caso do sequestro postulado diante da possível deterioração do bem levada a efeito por quem injustamente possui o bem. Diante dessa situação de perigo, o sequestro, sem dúvida, irá neutralizar a situação de perigo, porém sem satisfazer o direito daquele que supostamente tem direito à coisa. No entanto, também satisfação imediata do direito à coisa, com a entrega da coisa ao autor, irá neutralizar a situação de perigo. Porém, o que se deve entender 
Revista Eletrônica de Direito Processual - REDP. Volume 15. Janeiro a Junho de 2015 Periódico Semestral da Pós-Graduação Stricto Sensu em Direito Processual da UERJ. Patrono: José Carlos Barbosa Moreira. www.redp.com.br ISSN 1982-7636 PP 268-298

A categoria a que correspondia ao conceito de periculum in mora, dizia respeito a certas causas que, por sua simplicidade, ou por sua relevância, ou mesmo pela urgência com que exigiam uma resposta jurisdicional, recomendavam que as tratasse por meio de um processo sumário, enquanto a tutela concedida nos casos de perigo de damnun irreparabile a resposta jurisdicional nada tinha a ver com a natureza da causa, mas com a irrupção de um elemento ocasional de risco de dano iminente, capaz de correr, em princípio, com relação a qualquer causa.

Nas hipóteses em que se tutelava o direito com base no periculum in mora, cumpria-se uma das condições que determinaram a sumarização procedimental no Direito medieval: o encurtamento do tempo necessário à obtenção da tutela satisfativa, extirpando-se do procedimento ordinário todas as formalidades tornadas inúteis; nos casos de proteção contra o damnun irreparabile, ao contrário, a tutela se orientava no sentido da outorga de uma garantia jurisdicional contra um estado emergencial, surgindo em razão de circunstâncias extraordinárias e que permitiam que se protegesse o direito, sem que a provisão judicial o realizasse antecipadamente ${ }^{42}$.

$\mathrm{Na}$ primeira hipótese (periculum in mora) não são os eventos porventura surgidos como uma forma de anomalia circunstancial, a pôr em risco o direito da parte; ao contrário, é a própria causa que determina o tratamento diferenciado e sumário. É ela que não se compadece com a demora procedimental. Quanto ao periculum in mora, pois, sua ligação com a ideia de aceleração procedimental é inocultável, o que significa dizer que, aqui, a urgência decorre da lentidão própria do procedimento comum, contra o qual se concebe o tratamento diferenciado da causa, que, todavia, embora encurtada, continua ordinária ${ }^{43}$.

No Direito moderno, em virtude de circunstâncias históricas e doutrinárias especiais, universalizou-se o uso da categoria que os juristas medievais indicavam como periculum in mora, como se apenas ela tivesse correspondência entre essa categoria e o tratamento jurisdicional do damnum irreparabile. Em resumo, através de uma longa e persistente elaboração doutrinária, passou-se a considerar a tutela cautelar como

é que como requisito para a tutela cautelar a urgência se apresenta de modo mais restrito - ligada a uma situação externa ao processo - que para a concessão da tutela satisfativa de urgência. Sobre essa sensível distinção, ver RIBERIO, Darci Guimarães. Teoria geral da ação cautelar inominada. In: Da tutela jurisdicional às formas de tutela. Porto Alegre: Livraria do Advogado, 2010, p. 150.

${ }^{42}$ SILVA, Ovídio A. Baptista da. Do processo cautelar. Rio de Janeiro: Forense, 1996, p. 12.

${ }^{43}$ SILVA, Ovídio A. Baptista da. Do processo cautelar. Rio de Janeiro: Forense, 1996, p. 13. 
Revista Eletrônica de Direito Processual - REDP. Volume 15. Janeiro a Junho de 2015 Periódico Semestral da Pós-Graduação Stricto Sensu em Direito Processual da UERJ. Patrono: José Carlos Barbosa Moreira. www.redp.com.br ISSN 1982-7636 PP 268-298

proteção contra a morosidade do procedimento ordinário, o que, na verdade, afigura-se equivocado ${ }^{44}$.

Essa diferença no tocante à urgência foi bem percebida por Calamandrei, o qual dividia o periculum in mora em duas espécies: o pericolo di infruttuosità (perigo da infrutuosidade) e o pericolo di tardività (perigo da tardança). Nesta segunda espécie, conforme o jurista italiano, o provimento interinal visa a acelerar, de modo provisório, a satisfação do direito, porque o periculum in mora é constituído pelo retardo do estado de insatisfação do direito frente à demora do processo ordinário ${ }^{45}$. Já no perigo de infrutuosidade, o problema do tempo pauta-se numa situação objetiva de perigo ao direito que se quer assegurar. E, portanto, a sua demonstração torna-se imprescindível.

Apesar de ter escapado do Novo Código essa sensível diferença relativa à urgência conforme o tipo de tutela pleiteada, deve-se ver com bons olhos o fato de não se falar mais em perigo de dano irreparável ou de difícil reparação, mas somente em perigo de dano, que, bem entendido, deve ser lido como perigo de um efetivo prejuízo.

Em primeiro lugar, o perigo pode dizer respeito a um dano que seja, com certeza, reparável. Pense-se na situação em que se busca uma tutela provisória satisfativa (tutela antecipada) para reaver um bem que, injustamente, encontra-se na posse de outrem. A tutela provisória, no caso, evitará o prejuízo decorrente do fato de que o autor é que, em princípio arcaria com o ônus do tempo do processo, vale dizer, permaneceria com o seu suposto direito em estado de insatisfação até que sobreviesse a tutela definitiva. Tal prejuízo, no entanto, será facilmente reparável com a correspondente indenização, mormente quando é sabido que o réu possui vasto patrimônio. Então, nesse caso, a tutela provisória não tem relação necessária com o fato de ser irreparável o dano que se quer conter, mas com a própria natureza do direito, que, caso permaneça em estado de insatisfação durante o tempo normal do processo ocasionará um prejuízo ao autor, que ostenta um direito provável. Acertado, nessa linha, dizer que a tutela provisória satisfativa liga-se à necessidade de que o custo do tempo seja distribuído com equidade, de modo a não onerar exclusivamente um dos litigantes em benefício do seu adversário ${ }^{46}$.

\footnotetext{
${ }^{44}$ SILVA, Ovídio A. Baptista da. Do processo cautelar. Rio de Janeiro: Forense, 1996, p. 14.

${ }^{45}$ CALAMANDREI, Piero. Introduzione allo studio sistematico dei provvedimenti cautelari. Padova: CEDAM, 1936, p. 56.

${ }^{46}$ SILVA, Ovídio A. Baptista da. Tutela antecipatória e juízos de verossimilhança. In: Da sentença liminar à nulidade da sentença. Rio de Janeiro: Forense, 2002, p. 219.
} 
Revista Eletrônica de Direito Processual - REDP. Volume 15. Janeiro a Junho de 2015 Periódico Semestral da Pós-Graduação Stricto Sensu em Direito Processual da UERJ. Patrono: José Carlos Barbosa Moreira. www.redp.com.br ISSN 1982-7636 PP 268-298

Em segundo lugar, o perigo não precisa ser exclusivamente de dano. É que também o ilícito (ainda que não venha necessariamente a causar dano) deve ser neutralizado diante do problema do tempo do processo. Note-se que tal entendimento, há bastante tempo reconhecido na doutrina processual brasileira ${ }^{47}$, amolda-se ao tratamento conferido pelo Novo Código à matéria, o qual, no parágrafo único do seu art. 497, estabelece que "para a concessão da tutela específica destinada a inibir a prática, a reiteração ou a continuação de um ilícito, ou a sua remoção, é irrelevante a demonstração da ocorrência de dano ou da existência de culpa ou dolo".

No que diz respeito à tradução da urgência como "risco ao resultado útil do processo" o Novo Código deixa entrever, no seu bojo, uma nítida confusão conceitual. É que, para o Código, o direito à cautela repousa no plano do direito material (art. 305, Novo CPC), o que é incompatível com a ideia, bastante difundida no Brasil, de que a tutela cautelar teria como objetivo garantir o resultado útil do processo. O que a tutela cautelar visa a garantir é a frutuosidade do direito ${ }^{48}$, o que, somente por via reflexa, irá repercutir no resultado útil do processo.

\subsubsection{Elementos que evidenciem a probabilidade do direito}

O Novo CPC, ao exigir, para a concessão da tutela de urgência, "elementos que evidenciem a probabilidade do direito" corrige os problemas advindos da péssima redação do art. 273 do $\mathrm{CPC} / 73$, segundo a qual era necessária a existência de prova inequívoca e que o juiz se convencesse da verossimilhança da alegação. Ainda, sob a égide do Código de 1973, muita confusão se instaurou acerca da existência de possíveis diferenças quanto à probabilidade exigida para a tutela antecipada e para a tutela cautelar $^{49}$, em que pese a percuciente observação de Ovídio Baptista da Silva no sentido de que a cognição sumária fosse um pressuposto genérico para qualquer causa sumária $^{50}$. Com efeito, não há diferença no que tange à sumariedade da cognição na

\footnotetext{
${ }^{47}$ Sobre o tema, na doutrina brasileira, ver MARINONI, Luiz Guilherme. Tutela inibitória: Individual e coletiva. 4. ed. São Paulo: Rev. dos Tribunais, 2006.

${ }^{48}$ MARINONI, Luiz Guilherme. Processo cautelar. 2a ed. São Paulo: Revista dos Tribunais, 2010, p. 26.

${ }^{49}$ É o caso de Carlos Alberto Alvaro de Oliveira, para quem, na tutela antecipada, "exige-se algo mais do que na tutela cautelar e certamente menos do que na tutela dispensada em cognição plena e exauriente" (ALVARO DE OLIVEIRA, Carlos Alberto. Perfil dogmático da tutela de urgência. Revista da AJURIS, n. 70, Porto Alegre: 1997, p. 232).

50 SILVA, Ovídio A. Baptista da. Do processo cautelar. Rio de Janeiro: Forense, 1996, p. 13.
} 
Revista Eletrônica de Direito Processual - REDP. Volume 15. Janeiro a Junho de 2015 Periódico Semestral da Pós-Graduação Stricto Sensu em Direito Processual da UERJ. Patrono: José Carlos Barbosa Moreira. www.redp.com.br ISSN 1982-7636 PP 268-298

tutela antecipada e na tutela cautelar, uma vez que ambas têm como pressuposto um juízo de probabilidade ${ }^{51}$.

\section{Tutela antecipada antecedente e estabilização da tutela antecipada}

Uma das grandes inovações do Novo CPC no tocante à tutela provisória é a tutela antecipada antecedente. Até então, o direito brasileiro somente admitia que a tutela antecipada (satisfativa) fosse proferida de maneira incidental, no curso do processo de conhecimento, em face de pedido formulado pelo autor na petição inicial. Agora, no entanto, admite-se que o autor se limite, na petição inicial, a formular o pedido de tutela antecipada e apenas indique o pedido de tutela final, devendo, para tanto, fazer a exposição da lide, do direito que se busca realizar e o perigo de dano ou risco ao resultado útil do processo, vale dizer, o perigo na demora (art. 303, NCPC).

Sob um primeiro aspecto, a tutela antecipada antecedente preenche uma dupla finalidade. Por um lado, permite ao autor desenvolver com maior zelo o pedido de tutela antecipada satisfativa naquelas situações em que a urgência impõe a propositura imediata da ação, na medida em que poderá aprofundar as questões que versam sobre o pedido principal após ter formulado pedido de tutela antecipada. Por outro lado, evita que o autor, nos casos em que o indeferimento da tutela antecipada satisfativa tornar inútil o prosseguimento do feito em razão da perda do seu objeto, desenvolva um trabalho desnecessário, consistente na elaboração completa da petição inicial.

Há, no entanto, um segundo aspecto que justifica a criação da tutela de urgência antecedente. Trata-se da estabilização da tutela antecipada, que é, sem dúvida, uma das principais mudanças do Novo CPC. Tal instituto, nos moldes em que foi concebido no Código somente poderá ser bem compreendido se pensado em consonância com a tutela

\footnotetext{
${ }^{51}$ É importante mencionar que os conceitos de probabilidade e verossimilhança foram ao longo do tempo tratados como sinônimo, provavelmente em razão do clássico estudo de Calamandrei veritá $e$ verossimiglianza nel processso civile (CALAMANDREI, Piero. Veritá e verossimiglianza nel processso civile. Rivista di Diritto Processuale. Parte I. Padova: CEDAM, 1955). No entanto, há autores, como por exemplo, Michele Taruffo, que entendem serem diferentes a probabilidade e a verossimilhança, na medida em que esta última diria respeito à possibilidade de que algo normalmente ocorra. Verossimilhança, pois, diz respeito ao grau de capacidade representativa de uma dada descrição em relação à realidade e que é adotada como padrão para avaliar se a afirmação é ou não verossímil. A verossimilhança gravita no plano abstrato. Probabilidade, por sua vez, diz respeito a uma situação concreta e sua aptidão a corresponder em certa medida à realidade (TARUFFO, Michelle. La prova dei fatti giuridici: nozioni generali. Milano: Giuffrè, 1992, pp. 161-163). Para um diálogo entre a obra dos dois autores, ver, na doutrina nacional, FLACH, Daisson. A verossimilhança no processo civil e sua aplicação prática. São Paulo: Revista dos Tribunais, 2009.
} 
Revista Eletrônica de Direito Processual - REDP. Volume 15. Janeiro a Junho de 2015 Periódico Semestral da Pós-Graduação Stricto Sensu em Direito Processual da UERJ. Patrono: José Carlos Barbosa Moreira. www.redp.com.br ISSN 1982-7636 PP 268-298

antecipada antecedente, a qual, por sua vez, também deverá estar associada, na maioria das vezes, à estabilização da antecipação da tutela, como será visto mais adiante.

Para a tutela antecipada antecedente, o Novo CPC prevê um procedimento que, em face das suas peculiaridades e novidades, merece ser analisado com certo cuidado.

Com efeito, sendo concedida a tutela antecipada antecedente, o autor deverá aditar a petição inicial, com a complementação da sua argumentação, a juntada de novos documentos e a confirmação do pedido de tutela final, em 15 dias ou em outro prazo maior que o juiz fixar. O pedido de tutela final será processado e julgado nos mesmos autos, de modo que não haverá uma duplicidade de processos como ocorria no processo cautelar do Código de 1973. Importante mencionar que o autor deverá indicar na petição inicial que se trata de pedido de concessão de tutela antecipada requerido em caráter antecedente (art. 303, §5. ${ }^{\circ}$ ), hipótese na qual deverá indicar o valor da causa, levando em consideração, para tanto, o pedido de tutela final (art. 303, $\S 4 .^{\circ}$ ). As custas serão pagas no ato da distribuição do feito, não havendo incidência de novas custas quando do aditamento da petição inicial (art. 303, $\$ 3 .^{\circ}$ ). Registre-se, ainda, que, caso o autor não venha a aditar a petição inicial - o que obviamente é exigido na hipótese de concessão da tutela antecipada -, o processo será extinto sem resolução de mérito (art. $\left.303, \S 2 .^{\circ}\right)$.

Já na hipótese de ser negada a concessão da tutela antecipada, o autor terá o ônus de emendar a inicial no prazo de 5 dias, sob pena de ser indeferida e de o processo ser extinto sem resolução de mérito (art. $303, \S 6^{\circ} .^{\circ}$. É certo que isso não impede a interposição de recurso contra a decisão, uma vez que as decisões que versarem sobre tutela provisória sempre desafiarão agravo de instrumento (art. 1015, I, NCPC), o qual, pela sistemática do Novo Código, somente tem cabimento em situações típicas. Note-se, igualmente, que o Código fala em aditamento da petição inicial quando deferida a tutela antecipada, denotando, pois, a ideia de complementação do ato processual, e não de correção, como ocorre no caso de ser negado o pedido de concessão da tutela antecipada, em que o autor deverá corrigir a petição inicial, emendando-a, na medida em que não se tratava de hipótese de concessão de tutela antecipada antecedente.

Apesar de aparentemente simples, o procedimento da tutela antecipada antecedente somente poderá ser bem compreendido ao lado do instituto da estabilização da tutela antecipada, introduzido pelo art. 304 do Novo Código. Trata-se de um notável avanço no que tange à matéria. Com efeito, nos casos em que esta seja concedida de 
Revista Eletrônica de Direito Processual - REDP. Volume 15. Janeiro a Junho de 2015 Periódico Semestral da Pós-Graduação Stricto Sensu em Direito Processual da UERJ. Patrono: José Carlos Barbosa Moreira. www.redp.com.br ISSN 1982-7636 PP 268-298

forma antecedente o réu terá o ônus de impugnar a respectiva decisão mediante a interposição do respectivo recurso, sob pena de tornar-se estável a tutela concedida ${ }^{52}$.

O Código adota, nesse passo, a chamada técnica monitória ${ }^{53}$, a qual tem como finalidade superar a inércia do réu, colocando o autor numa posição inicial de vantagem $^{54}$. Há, na estabilização da antecipação da tutela antecipada, assim como no procedimento monitório, uma inversão do contraditório, que será eventual ${ }^{55}$. Dito de outro modo, a inércia do réu irá influir diretamente na profundidade da cognição judicial, que somente será exauriente se houver impugnação à decisão em que concedida a tutela antecipada ${ }^{56}$.

Sob um primeiro olhar, a estabilização da tutela antecipada encontra-se respaldada nas situações em que Ovídio Baptista da Silva nominava de "tutela sumária autônoma", vale dizer, naquelas hipóteses em que a antecipação da tutela - no que concerne aos seus efeitos - não tem nada de provisória, na medida em que impõem consequências que somente poderão ser reparadas por alguma forma subsequente de reposição monetária ${ }^{57}$. Um exemplo bastante atual seria a concessão de tutela

\footnotetext{
${ }^{52}$ Art. 304. A tutela antecipada, concedida nos termos do art. 303, torna-se estável se da decisão que a conceder não for interposto o respectivo recurso.

${ }^{53}$ LEONEL, Ricardo de Barros. Tutelas jurisdicionais diferenciadas no Projeto do Novo Código de Processo Civil. Revista de informação legislativa. Brasília. Ano 48. n. 190. Abr./jun. 2011, p. 186. Entendimento que há muito já vinha sendo defendido no Brasil a partir dos primeiros projetos de lei acerca da estabilização da antecipação da tutela. Nesse sentido, ver GRINOVER, Ada Pellegrini. Tutela jurisdicional diferenciada: A antecipação e sua estabilização. Revista de Processo São Paulo, rev. dos tribunais, n. 121, p. 11-37, mar, 2005.

${ }^{54}$ PERROT, Roger. Il procedimento per ingiunzione - studio di diritto comparato. Rivista di diritto processuale, 1986, p. 716.

${ }^{55} \mathrm{Na}$ doutrina brasileira, entendendo pela existência de contraditório eventual no procedimento monitório e, consequentemente, de cognição exauriente a depender da atitude do réu, ver TUCCI, José Rogério Cruz e. Ação monitória: Lei 9.079, de 14.07.1995. 3. ed. São Paulo: Rev. dos Tribunais, 2001. TALAMINI, Eduardo. Tutela monitoria: A ação monitoria. Lei 9.079/95. 2. ed. São Paulo: Rev. dos Tribunais, 2001. MARCATO, Antônio Carlos. Procedimentos especiais. 13. ed. São Paulo: Atlas, 2007, p. 275, MACEDO, Elaine Harzheim. Do procedimento monitório. São Paulo: Rev. dos Tribunais, 1999. Sobre o procedimento monitório, na doutrina estrangeira, ver CALAMANDREI, Piero. Il procedimento monitorio nella legislazione italiana. In: Opere giuridiche (a cura di Mauro Cappelletti), v.3, Napoli: Morano, 1983. GARBAGNATI, Edoardo. I procedimenti di ingiunzione e sfratto. 2. ed. Milano: Giuffrè, 1949.

${ }^{56}$ Entendendo pela eventualidade da cognição exauriente no procedimento monitório, Elaine Macedo afirma que, no procedimento monitório, só haverá cognição se o demandado tomar a iniciativa do contraditório, daí por que sua eventualidade. Instaurado o contraditório, poderá conforme o caso, a atividade cognitiva ser plena ou limitada, conforme haja ou não redução no objeto litigioso, com exame, porém exaustivo da questão posta no seu sentido vertical (MACEDO, Elaine Harzheim. Do procedimento monitório. São Paulo: Rev. dos Tribunais, 1999, p. 32). No mesmo sentido, Kazuo Watanabe, que também considera como hipótese de cognição eventual, plena ou limitada, e exauriente, a ação de prestação de contas - nominada pelo Novo Código de ação de exigir contas - na qual a cognição somente será plena na primeira fase do procedimento se o réu negar o dever de prestar contas (WATANABE, Kazuo. Da cognição no processo civil. 2. ed. Campinas: Bookseller, 2000, p. 120).

${ }^{57}$ SILVA, Ovídio A. Baptista da. Curso de processo civil. v.2. Processo cautelar (tutelas de urgência) 4. ed., rev. atual. Rio de Janeiro: Forense, 2007-2008, pp. 70-71. Na referida obra, Ovídio fornece diversos
} 
Revista Eletrônica de Direito Processual - REDP. Volume 15. Janeiro a Junho de 2015 Periódico Semestral da Pós-Graduação Stricto Sensu em Direito Processual da UERJ. Patrono: José Carlos Barbosa Moreira. www.redp.com.br ISSN 1982-7636 PP 268-298 antecipada para a realização de uma cirurgia sob as expensas do Estado ou até mesmo para a obtenção de um medicamento. Tendo sido satisfeito o seu direito, antes mesmo do processo ter iniciado, o autor não apresentará interesse no prosseguimento do feito.

Nada obsta, porém, que a tutela antecipada antecedente seja requerida em casos de uma tutela satisfativa cujos efeitos sejam provisórios. É possível, por exemplo, que o pedido de tutela final formulado pelo autor limite-se à exclusão do seu nome dos órgãos de proteção ao crédito, em decorrência de uma cobrança que ele considera indevida. Nesse caso, argumentaria que a inclusão do seu nome seria um ato ilícito, na medida em que inexistente a dívida. Concedida a antecipação da tutela, esta fundada em juízo sumário sobre a suposta inexistência do débito - que constitui causa de pedir na demanda em que se postula unicamente a tutela jurisdicional mandamental para remoção do ato ilícito (inscrição nos órgãos de proteção ao crédito) - poderá o autor não ter interesse em controverter, com juízo de cognição exauriente, outras questões, como a própria inexistência do débito e a correspondente declaração judicial nesse sentido, ou até eventual direito à indenização por danos morais decorrentes da cobrança indevida que teria sido realizada pela parte ré.

Os exemplos referidos são bastante elucidativos, tendo-se como ponto de partida o raciocínio inicial de que a estabilização da tutela e a tutela antecedente, em regra, deverão ser trabalhadas em conjunto. É que a possibilidade de uma tutela antecipada antecedente, vale dizer, requerida e concedida antes da apresentação da "lide" em sua totalidade, deve ser pensada como um benefício para o autor ${ }^{58}$, o qual, diante da inércia do réu, não precisará mais controverter a "lide principal" naquele mesmo processo, pois já obteve, com base em juízo sumário, os efeitos pretendidos com a tutela final definitiva. O Código, nesse propósito, apresenta uma nítida tentativa de romper com o paradigma da ordinariedade tão presente na doutrina processual brasileira ${ }^{59}$.

Não é demasiado lembrar que, há cerca de 15 anos, Ovídio Baptista criticava a noção de cognição sumária adotada por notáveis processualistas brasileiros, dizendo

exemplos do que ele nominava tutela satisfativa autônoma, dentre os seguintes: o caso do locador que postula a possibilidade de realizar reparos urgentes no imóvel locado quando há resistência pelo inquilino; a liberação dos cruzados retidos Governo Federal em razão de planos econômicos; a prorrogação do contrato de seguro para determinar que a seguradora pagasse ao segurado as despesas de hospitalização previstas na apólice.

${ }^{58}$ Não é por menos que o $\S 5^{\circ}$ do art. 303 do NCPC exige que o autor, quando requerer a tutela antecedente prevista no caput deverá indicá-la na petição inicial, utiliza a expressão benefício.

${ }^{59}$ Sobre o tema, ver SILVA, Ovídio Araújo Baptista da. Processo e ideologia: o paradigma racionalista. 2. ed. Rio de Janeiro: Forense, 2006. SILVA, Ovídio A. Baptista da. Jurisdição e execução na tradição romano-canônica. 3. ed., rev. Rio de Janeiro: Forense, 2007. 
Revista Eletrônica de Direito Processual - REDP. Volume 15. Janeiro a Junho de 2015 Periódico Semestral da Pós-Graduação Stricto Sensu em Direito Processual da UERJ. Patrono: José Carlos Barbosa Moreira. www.redp.com.br ISSN 1982-7636 PP 268-298 que, para eles, cognição sumária não significaria nada mais do que "aquela legitimação de um juízo sumário, à espera de confirmação, no curso da ação, cuja cognição final a completará" ${ }^{60}$. A adoção da estabilização da antecipação da tutela justamente permite, através das técnicas da sumarização e da inversão do contraditório, que o juiz decida com base em cognição sumária (tanto quanto à profundidade da cognição quanto à amplitude das questões que compõem a lide, estas limitadas pelo fato de o réu não ter se manifestado) com alto grau de estabilidade, ao ponto de que a sua decisão somente poderá ser revertida se for proposta uma nova ação ${ }^{61}$. Vale dizer, a cognição sumária não estará mais à espera de confirmação pela decisão definitiva a ser proferida no mesmo processo, pois a amplitude da cognição, uma vez deferida a tutela antecipada, dependerá de ato positivo do réu, ou seja, a interposição do respectivo recurso contra a decisão. Somente nesse caso o autor terá o ônus de confirmar o pedido principal e dar prosseguimento ao processo $^{62}$.

${ }^{60}$ SILVA, Ovídio A. Baptista da. O contraditório nas ações sumárias. Revista da AJURIS. Ano XXV. №. 80. Dezembro de 2000. Porto Alegre: AJURIS, 2000, p. 214.

${ }^{61}$ A questão da sumarização material, seja no plano horizontal, seja no plano vertical da cognição, é um dos temas chaves para a compreensão da tutela provisória e, principalmente, da estabilização da antecipação da tutela. É que o referido instituto permite, de acordo com o caso concreto, uma decisão dotada de estabilidade, mas fundada em cognição sumária. O mais interessante aqui é que não somente a decisão será proferida sem o grau de profundidade da chamada cognição exauriente, como também poderá deixar de levar em consideração defesas materiais não arguidas pelo réu, ou questões que poderiam compor a lide total, mas que sequer foram levantadas pelo autor, que se limita a requerer a tutela antecipada, e não, no momento, a tutela final, que poderá ser mais ampla. Note-se que, no caso da ação possessória, em que a cognição está limitada à posse, questões que poderiam servir de defesa para o réu deverão ser deduzidas como causa de pedir de uma ação subsequente. Esse corte visa a "atender à necessidade imediata de algum interesse capaz de ser sacrificado pelo periculum in mora", o que no direito antigo seria feito numa fase subsequente da mesma demanda, havendo uma espécie de "reserva de exceções". Ainda bastante esclarecedora para a compreensão do tema é seguinte lição de Ovídio Baptista da Silva: "à medida que reduzimos o número de pretensões de direito material, agrupando numa única lide as questões litigiosas que poderiam compor duas ou mais demandas diferentes, aumentamos-lhes a complexidade, com as naturais consequências disso decorrentes, ao passo que, se as pulverizamos em lides parciais, distribuindo por muitas ações aquelas questões formadoras da imaginada lide total, criaríamos ações de pequena complexidade, capazes de permitir soluções rápidas e seguras" (SILVA, Ovídio A. Baptista da. O contraditório nas ações sumárias. Revista da AJURIS. Ano XXV. № 80. Dezembro de 2000. Porto Alegre: AJURIS, 2000, p. 213).

${ }^{62}$ É certo que a estabilização prevista no direito brasileiro difere daquela constante em outros ordenamentos jurídicos, como o francês e o italiano, em que uma vez deferida a tutela provisória, ao réu não cabe apenas o ônus de impugná-la, mas de apresentar o pleito de cognição plena. Nesse sentido, Humberto Theodoro Junior e Érico Andrade, advertem: Percebe-se que o modelo brasileiro criou uma perspectiva procedimental diversa, para autonomização e estabilização da tutela, daquelas encontradas no direito italiano e no direito francês, pois: a) criou o procedimento antecedente para busca da tutela da urgência, mas determinou que o próprio autor é que deverá, uma vez impugnada a medida antecipatória pelo réu, apresentar o pleito de cognição plena (art. 282 do PL): no sistema italiano e francês este ônus é invertido para o próprio réu: deferida a tutela sumária, o procedimento se fecha, e cabe ao réu buscar a tutela no processo de cognição plena, como autor deste; b) criou uma passagem no procedimento de cognição sumária, antecedente, para o procedimento de cognição plena: o primeiro, uma vez impugnada a medida pelo réu, irá se convolar no procedimento de cognição plena, mediante apresentação, pelo próprio autor, do pedido inicial (art. 282, § 1. ${ }^{\circ}$ ). (THEODORO JÚNIOR, Humberto; ANDRADE, Érico. A 
Revista Eletrônica de Direito Processual - REDP. Volume 15. Janeiro a Junho de 2015 Periódico Semestral da Pós-Graduação Stricto Sensu em Direito Processual da UERJ. Patrono: José Carlos Barbosa Moreira. www.redp.com.br ISSN 1982-7636 PP 268-298

Tanto é assim que, para o Novo $\mathrm{CPC}$, se o réu não recorrer de decisão que concedeu a tutela antecipada, esta tonar-se-á estável (art. 304) e o processo será extinto. E, mesmo com a extinção do processo, a tutela antecipada conservará seus efeitos (art. $\left.304, \S 3 .^{\circ}\right)$. Somente com a propositura de uma nova ação por parte do réu, em que revisada, reformada ou invalidada a tutela antecipada, é que os efeitos poderão ser cessados. Referida ação deverá ser proposta no prazo de dois anos, contados do prazo de 2 anos da decisão que extinguiu o processo em face da estabilização da tutela antecipada (art. 304, §5..$^{\circ}$. Apesar disso, a decisão concessiva da antecipação da tutela será incapaz de produzir coisa julgada (art. 304, $\S 6^{\circ}$ ), o que não pode ser confundido com ausência de estabilidade da decisão. Por sinal, a doutrina contemporânea tem demonstrado notáveis esforços no sentido de conferir um tratamento conjunto para as estabilidades dos atos processuais, com a superação da abordagem cognitivista da estabilidades processuais, que as concentra na declaração sobre o mérito, e não na "normatividade" do vínculo decorrente do ato processual, de modo a estender o caráter regulatório até então atribuído à declaração sobre o mérito também aos efeitos do ato jurisdicional, levando-se em consideração os seus impactos em outros atos e processos ${ }^{63}$, prestigiando-se, assim, a segurança jurídica e a boa-fé.

A ausência de coisa julgada, porém, não importa na ausência de exame do mérito na decisão que concede a tutela antecipada estabilizada. De fato, a decisão que aprecia a tutela antecipada sempre importará na apreciação do mérito, sem que isso signifique resolvê-lo. Afinal a decisão não será proferida com base em cognição exauriente. Não haverá declaração - com força de coisa julgada - sobre o mérito. Desse modo, ainda que estabilizada a tutela antecipada, o autor não poderá, por exemplo, valer-se dos efeitos positivos da coisa julgada tendo como pressuposto a decisão que concedeu a tutela antecipada. Isso não significa, por outro lado, que a decisão possa ser

autonomização e a estabilização da tutela de urgência no projeto de CPC. Revista de Processo, São Paulo, v. 37, n. 206, p.13-59, abr. 2012).

${ }^{63}$ CABRAL, Antônio do Passo. Coisa julgada e preclusões dinâmicas: entre continuidade, mudança e transição de posições processuais estáveis. $2^{\mathrm{a}}$ ed. Salvador: Juspodivm, 2014, p. 269. Referido autor, responsável pela principal obra sobre o tema das estabilidades no direito brasileiro, afirma que "compreender as estabilidades processuais como um fenômeno geral, comum a todos os atos de qualquer processo, permite pensar outras formas de estabilidade que não a coisa julgada, o que será um grande passo na ultrapassagem dos métodos tradicionais que procuravam testar a aplicação da coisa julgada (apenas um caso específico de estabilidade) a outros atos ou procedimentos" (p. 270) 
Revista Eletrônica de Direito Processual - REDP. Volume 15. Janeiro a Junho de 2015 Periódico Semestral da Pós-Graduação Stricto Sensu em Direito Processual da UERJ. Patrono: José Carlos Barbosa Moreira. www.redp.com.br ISSN 1982-7636 PP 268-298

ignorada ou mesmo que os fundamentos que levaram a concessão da tutela antecipada possam ser ignorados em outro processo ${ }^{64}$.

Bem entendida a estabilização da tutela antecipada como um benefício do autor, que implica a inversão do contraditório com uma cognição plena apenas eventual, é possível compreender, na sua totalidade, o procedimento da tutela antecipada antecedente.

Com efeito, voltando à questão acerca do aditamento da petição inicial quando deferida a tutela antecipada, deve-se ter em mente que não haveria sentido tal determinação ocorrer antes de transcorrido o prazo para o réu recorrer da decisão concessiva da tutela antecipada. Note-se que o benefício concedido ao autor a partir da técnica da inversão do contraditório cairia por terra se este tivesse que complementar a petição inicial antes mesmo de saber se houve a estabilização da tutela antecipada ${ }^{65}$. É que uma das questões fulcrais da estabilização reside no fato de o autor, após obtê-la, não precisar dar continuidade ao processo - o que ocorrerá somente se o réu não recorrer. Logo, não haveria nenhum sentido dizer que o contraditório e a cognição plena são eventuais se, mesmo quando réu fosse omisso diante da tutela antecipada concedida ao autor, este fosse obrigado a continuar o processo.

Disso tudo, pode-se concluir que a melhor forma de entender o procedimento da tutela antecipada antecedente quando esta houver sido deferida é o seguinte: o réu deverá ser, primeiramente, intimado da decisão que concede a tutela antecipada antecedente e, somente depois de expirado o prazo para o recurso, é que ocorrerá a intimação do autor para o aditamento da petição inicial (art. 303, $\S 1 .^{\circ}$, I). Caso o réu deixe de recorrer, o processo será extinto; porém, se o réu recorrer, será determinada a sua citação e intimação para a audiência do art. 334 do Novo CPC (art. 303, § $1^{\circ}$., II) ou, se for o caso, somente para contestar. Ainda nessa linha, o recurso interposto pelo réu terá dupla função: através dele, o réu manifestará seu interesse na causa, afastando a possibilidade de estabilização da tutela antecipada ao mesmo tempo que se insurgirá

\footnotetext{
${ }^{64}$ Novamente pode-se citar como base para tais conclusões a obra de Antônio do Passo Cabral, "Coisa julgada e preclusões dinâmicas".

${ }^{65}$ Nas primeiras versões do projeto do Novo CPC a estabilização decorria da ausência de impugnação da medida liminar, que poderia ser interpretada tanto como recurso, quanto como contestação. Além disso, o prazo para aditamento da petição inicial, caso concedida a liminar, tinha como marco inicial a referida impugnação, dispensando-se a apresentação do pedido principal quando não impugnada a medida liminar. Apesar de o Novo Código exigir o recurso da decisão, e não uma simples contestação (tanto que utiliza a expressão recurso, e não impugnação), mantém-se a mesma lógica de que não há sentido o autor aditar a petição antes de saber se a tutela antecipada será estabilizada.
} 
Revista Eletrônica de Direito Processual - REDP. Volume 15. Janeiro a Junho de 2015 Periódico Semestral da Pós-Graduação Stricto Sensu em Direito Processual da UERJ. Patrono: José Carlos Barbosa Moreira. www.redp.com.br ISSN 1982-7636 PP 268-298

contra a própria decisão que a concedeu. Ainda que o recurso venha a ser provido e o autor já tenha aditado a petição inicial, tal ato processual poderá ser aproveitado, pois do ponto de vista prático a conduta exigida do autor, conforme seja caso de aditar ou de emendar a petição inicial, será a mesma. Para o caso de o recurso não ser provido, o Novo Código não diz se haverá a estabilização da tutela antecipada. No entanto, o entendimento de que frente à negativa de provimento do recurso haverá a estabilização da tutela antecipada parece prestigiar o instituto e atender às suas reais finalidades.

Por outro lado, uma vez estabilizada a tutela antecipada com a consequente conservação dos seus efeitos, o autor não necessitará, em princípio, aditar a petição inicial, na medida em que o processo será extinto (art. 304, §1 $.^{\circ}, \mathrm{NCPC}$ ). Porém, caso existam outras questões pertinentes a mesma lide, como as mencionadas no exemplo anterior, ou seja, o pedido de declaração de inexistência de débito ou o pedido de indenização por danos morais, o autor deverá propor uma nova ação para discuti-las. Somente se os outros pedidos tiverem sido também indicados na petição inicial é que se poderá cogitar da possibilidade de aditamento da inicial, apesar de ter sido estabilizada a tutela antecipada, para que, no mesmo processo, sejam discutidas as demais questões. Embora, é importante frisar, tal solução de aditamento da petição inicial - aqui apresentada como alternativa à proposição anterior no sentido da necessidade de uma nova ação - vai de encontro à previsão do art. 304, §1. ${ }^{\circ}, \mathrm{NCPC}$, segundo o qual havendo estabilização ocorrerá a extinção do processo sem resolução de mérito.

Por fim, questão que certamente dará margem à dúvida é a da condenação do réu ao pagamento de despesas processuais e honorários caso ocorra a estabilização da tutela antecipada. Nesses casos, parece adequado que se aplique o mesmo regime da ação monitória quando o réu cumpre no prazo legal o mandado monitório. Com efeito, o réu deverá ser condenado ao pagamento de honorários advocatícios em 5\% sobre o valor da causa (art. 701), ficando isento do pagamento das despesas processuais (art. 701, $\S 1^{\circ}$ ).

\section{Considerações finais}

O Novo CPC buscou dar sistematização ao tema da tutela provisória, na medida em que veio alçá-la à condição de gênero dentro do qual são desenvolvidas a tutela cautelar e a tutela satisfativa de urgência e da evidência. $O$ critério classificatório cujo ponto de partida é a tutela jurisdicional do direito, no caso, a tutela cautelar e a tutela satisfativa, em que pese seja bastante profícuo, não foi expressamente adotado pelo 
Revista Eletrônica de Direito Processual - REDP. Volume 15. Janeiro a Junho de 2015 Periódico Semestral da Pós-Graduação Stricto Sensu em Direito Processual da UERJ. Patrono: José Carlos Barbosa Moreira. www.redp.com.br ISSN 1982-7636 PP 268-298 Novo CPC, no qual optou-se por dividir a tutela provisória em tutela de urgência e da evidência. Trata-se de uma divisão que parte dos critérios para a concessão da tutela provisória e que, por essa razão, não oferece clareza quanto à espécie de tutela (cautelar ou satisfativa) oferecida ao direito material. Daí o importante papel que cabe à doutrina, de esclarecer em que medida a tutela material do direito (cautelar ou satisfativa) se insere no âmbito da tutela provisória.

Nesse sentido, é induvidoso que a expressão tutela antecipada, presente no Novo CPC, deve ser lida como sinônimo de tutela satisfativa de urgência, conferida em caráter provisório. Do mesmo modo, a tutela da evidência deve ser visualizada como tutela satisfativa fundada na evidência do direito, conferida em caráter provisório.

Quanto à tutela cautelar, o Novo Código chancela conquistas teóricas significativas. Em primeiro lugar, rompe com a ideia de que a tutela cautelar tenha como objetivo proteger o processo. Isso fica bastante claro quando se exige, para a sua concessão, a exposição sumária do direito que se objetiva assegurar. Em segundo lugar, acaba com o "processo cautelar", permitindo que a tutela cautelar seja conferida tanto antes do processo em que busca a realização do direito, quanto de forma incidental, no bojo do mesmo processo. Acaba-se, desse modo, com a incômoda duplicidade de processos que existia no antigo Código. Além disso, o Novo Código deixa de nominar procedimentos cautelares, limitando-se a exemplificar algumas medidas capazes de efetivar a tutela cautelar, o que, sem dúvida, exigirá de todos aqueles que lidam com o processo civil uma adequada compreensão da teoria da tutela cautelar.

Talvez a novidade mais expressiva quanto ao tema da tutela provisória seja a estabilização da tutela antecipada, instituto há bastante tempo reivindicado por importante parcela da doutrina processual brasileira. No entanto, a possibilidade de obstar a estabilização mediante a interposição de um recurso é, sem dúvida, um elemento que poderá frustrar a utilidade do instituto, notadamente se o procedimento da tutela antecipada antecedente não for compreendido com olhos voltados para a sua estabilização $^{66}$. Justamente por isso, buscou-se, no presente ensaio, oferecer uma

\footnotetext{
${ }^{66}$ Deixe-se claro, na linha da doutrinária de Humberto Theodoro Junior e Érico Andrade, anteriormente mencionada, que o direito brasileiro adotou uma posição talvez até tímida quanto ao instituto da estabilização da tutela antecipada, ao atribuir ao réu a possibilidade de interpor um recurso com vistas a obstar a estabilização. Essa opção legislativa, diga-se de passagem criticável, dá a antecipação da tutela um tratamento diferenciado inclusive àquele previsto na ação monitória, pois nesta a inversão do contraditório fica caracterizada pelo ônus atribuído ao réu de opor os embargos à ação monitória, enquanto isso, no âmbito da tutela antecipada, o réu tem o ônus de recorrer da decisão e, caso não venha a fazê-lo, ainda poderá voltar a questão, com a propositura da ação prevista no art. $304, \S 2^{\circ}$, do NCPC.
} 
Revista Eletrônica de Direito Processual - REDP. Volume 15. Janeiro a Junho de 2015 Periódico Semestral da Pós-Graduação Stricto Sensu em Direito Processual da UERJ. Patrono: José Carlos Barbosa Moreira. www.redp.com.br ISSN 1982-7636 PP 268-298

proposta de harmonização e interpretação dos dispositivos que versam sobre a tutela antecipada antecedente e a estabilização da antecipação da tutela de modo que possam ser aplicados do melhor modo possível. Trata-se de ponto crucial para a viabilidade da estabilização da tutela antecipada, razão pela qual é imprescindível o seu amadurecimento a partir de franco debate doutrinário.

\section{REFERÊNCIAS BIBLIOGRÁFICAS}

AlVARO DE OLIVEIRA, Carlos Alberto. Perfil dogmático da tutela de urgência. Revista da AJURIS, n. 70, Porto Alegre: 1997.

ANDOLINA, Italo. Il tempo e il processo. Revista de processo. Ano 34. n. 176. out./2009.

BARBOSA MOREIRA, José Carlos. Eficácia da sentença e autoridade da coisa julgada. In: Temas de direito processual: terceira série. São Paulo: Saraiva, 1984.

CABRAL, Antônio do Passo. Coisa julgada e preclusões dinâmicas: entre continuidade, mudança e transição de posições processuais estáveis. $2^{\mathrm{a}}$ ed. Salvador: Juspodivm, 2014.

CALAMANDREI, Piero. Veritá e verossimiglianza nel processso civile. Rivista di diritto processuale. Parte I. Padova: CEDAM, 1955.

. Introduzione allo studio sistematico dei provvedimenti cautelari. Padova:

CEDAM, 1936.

. Il procedimento monitorio nella legislazione italiana. In: Opere giuridiche (a cura di Mauro Cappelletti), v.3, Napoli: Morano, 1983.

CARNELUTTI, Francesco. Diritto e processo Nápoles: Morano, 1958.

CHAINAIS, Cécile. La protection juridictionnelle provisoire dans le procès civil en droit français et italien. Paris: Dalloz, 2007.

CHIOVENDA, Giuseppe. Azioni sommarie: la sentenze di condanna con riserva. In: CHIOVENDA, Giuseppe. Saggi di diritto processuale civile (1900-1930). v. 2. Roma: Foro Italiano, 1930-1931.

COMOGLIO, Luigi Paolo. Durata ragionevole del giudizio e forme alternative di tutela. Revista de processo. Ano 32. n. 151. Set/2007 
Revista Eletrônica de Direito Processual - REDP. Volume 15. Janeiro a Junho de 2015 Periódico Semestral da Pós-Graduação Stricto Sensu em Direito Processual da UERJ. Patrono: José Carlos Barbosa Moreira. www.redp.com.br ISSN 1982-7636 PP 268-298

COSTA, Eduardo José da Fonseca. Sentença cautelar, cognição e coisa julgada: reflexões em homenagem à memória de Ovídio Baptista. Revista de Processo, São Paulo, v. 36, n. 191, p. 357-376, jan. 2011.

FAIREN GUILLEN, Victor. El juicio ordinario y los plenarios rapidos (los defectos en la recepcion del derecho procesal comun; sus causas y consecuencias en doctrina y legislacion actuales). Barcelona: Bosch, 1953.

FICARELLI, Beatrice. Fase preparatoria del processo civile e case management giudiziale. Napoli: Edizioni Scientifiche Italiane, 2011.

FLACH, Daisson. A verossimilhança no processo civil e sua aplicação prática. São Paulo: Revista dos Tribunais, 2009.

FUX, Luiz. Tutela de segurança e tutela da evidência (fundamentos da tutela antecipada). São Paulo: Saraiva, 1996.

GARBAGNATI, Edoardo. I procedimenti di ingiunzione e sfratto. 2. ed. Milano: Giuffrè, 1949.

GRINOVER, Ada Pellegrini. Tutela jurisdicional diferenciada: A antecipação e sua estabilização. Revista de Processo São Paulo, rev. dos tribunais, n. 121, p. 11-37, mar, 2005.

JOBIM, Marco Félix. O direito à duração razoável do processo: responsabilidade civil do Estado em decorrência da intempestividade processual. 2. ed. Porto Alegre: Liv. do Advogado, 2012.

JOMMI, Alessandro. Il référé provision: ordinamento francese ed evoluzione della tutela sommaria anticipatoria in Itália. Torino: G. Giappichelli, 2005.

LACERDA, Galeno. Comentários ao Código de Processo Civil: v.8, t.1 (arts. 796 a 812). 10. ed. Rio de Janeiro: Forense, 2007.

LEONEL, Ricardo de Barros. Tutelas jurisdicionais diferenciadas no Projeto do Novo Código de Processo Civil. Revista de informação legislativa. Brasília. Ano 48. n. 190. Abr./jun. 2011.

. Tutela jurisdicional diferenciada. São Paulo: RT, 2010.

LOPES DA COSTA, Alfredo Araújo. Medidas preventivas: medidas preparatórias medidas de conservação. 3a ed., São Paulo: Sugestões Literárias, 1966.

LOPES, Bruno Vasconcelos Carrilho. Tutela antecipatória sancionatória. São Paulo: Malheiros, 2006. 
Revista Eletrônica de Direito Processual - REDP. Volume 15. Janeiro a Junho de 2015 Periódico Semestral da Pós-Graduação Stricto Sensu em Direito Processual da UERJ. Patrono: José Carlos Barbosa Moreira. www.redp.com.br ISSN 1982-7636 PP 268-298 MACEDO, Elaine Harzheim. Do procedimento monitório. São Paulo: Rev. dos Tribunais, 1999.

MARCATO, Antônio Carlos. Procedimentos especiais. 13. ed. São Paulo: Atlas, 2007. MARINONI, Luiz Guilherme. Processo cautelar. 2a ed. São Paulo: Revista dos Tribunais, 2010.

. Abuso de defesa e parte incontroversa da demanda. São Paulo: Revista dos Tribunais, 2007.

. Tutela inibitória: Individual e coletiva. 4. ed. São Paulo: Rev. dos Tribunais, 2006.

. Técnica processual e tutela dos direitos. São Paulo: Revista dos Tribunais, 2004

MITIDIERO, Daniel. Antecipação da tutela: da tutela cautelar à técnica antecipatória. São Paulo: Revista dos Tribunais, 2013.

- Tutela antecipatória e defesa inconsistente. In: Tutelas de urgência e cautelares / Estudos em homenagem a Ovídio A. Baptista da Silva / coordenador Donaldo Armelin. São Paulo: Saraiva, 2010.

PAIM, Gustavo Bohrer. O référé francês. Revista de Processo, São Paulo, v. 37, n. 203, p. 99-118, jan. 2012.

PROTO PISANI, Andrea. Dai riti speciali ala differenziazione del rito ordinario. Il foro italiano. Roma: Il foro italiano, 2006.

- La tutela sommaria in generale e il procedimento per ingiuzione nell'ordinamento italiano. Revista de processo. n. 90. Ano 23. Abril-Junho de 1998. . Lezioni di diritto processuale civile. Napoli: Jovene, 1999.

. Sulla tutela giurisdizionale differenziata. Rivista di diritto processuale, n. 4, Padova: Cedam, 1979.

RIBERIO, Darci Guimarães. Teoria geral da ação cautelar inominada. In: Da tutela jurisdicional às formas de tutela. Porto Alegre: Livraria do Advogado, 2010.

SILVA, Ovídio A. Baptista da. Jurisdição, direito material e processo. Rio de Janeiro: Forense, 2008.

. Curso de processo civil. v.2. Processo cautelar (tutelas de urgência) 4. ed., rev. atual. Rio de Janeiro: Forense, 2007-2008.

. Jurisdição e execução na tradição romano-canônica. 3. ed., rev. Rio de Janeiro: Forense, 2007. 
Revista Eletrônica de Direito Processual - REDP. Volume 15. Janeiro a Junho de 2015 Periódico Semestral da Pós-Graduação Stricto Sensu em Direito Processual da UERJ. Patrono: José Carlos Barbosa Moreira. www.redp.com.br ISSN 1982-7636 PP 268-298 . Processo e ideologia: o paradigma racionalista. 2. ed. Rio de Janeiro: Forense, 2006.

. A "plenitude de defesa" no processo civil. In: Da sentença liminar à nulidade da sentença. Rio de Janeiro: Forense, 2002.

. Tutela antecipatória e juízos de verossimilhança. In: Da sentença liminar à nulidade da sentença. Rio de Janeiro: Forense, 2002.

. O contraditório nas ações sumárias. Revista da Ajuris. Ano XXVI. n. 80. Porto Alegre: Ajuris, 2000. . Do processo cautelar. Rio de Janeiro: Forense, 1996

. Decisões interlocutórias e sentenças liminares. AJURIS: Revista da Associação dos Juízes do Rio Grande do Sul, Porto Alegre, v.18, n.51, mar. 1991. . Procedimentos especiais. Rio de Janeiro: Aidê, 1989.

TALAMINI, Eduardo. Tutela monitoria: A ação monitoria. Lei 9.079/95. 2. ed. São Paulo: Rev. dos Tribunais, 2001.

TARUFFO, Michelle. La prova dei fatti giuridici: nozioni generali. Milano: Giuffrè, 1992.

THEODORO JÚNIOR, Humberto. Curso de direito processual civil: v.2. 49. ed. Rio de Janeiro: Forense, 2014.

THEODORO JÚNIOR, Humberto; ANDRADE, Érico. A autonomização e a estabilização da tutela de urgência no projeto de CPC. Revista de Processo, São Paulo, v. 37, n. 206, p.13-59, abr. 2012.

TOMMASEO, Ferruccio. I provvedimenti d'urgenza: struttura e limiti della tutela antecipatoria. Padova: CEDAM, 1983.

TUCCI, José Rogério Cruz e. Ação monitória: Lei 9.079, de 14.07.1995. 3. ed. São Paulo: Rev. dos Tribunais, 2001.

. Tempo e processo: uma análise empírica das repercussões do tempo na fenomenologia processual (civil e penal). São Paulo: Rev. dos Tribunais, 1997.

WAMBIER, Luiz Rodrigues; ALVIM, Teresa Celina Arruda. Tutela diferenciada. Revista de Processo, São Paulo, v.35, n.180. São Paulo: Revista dos Tribunais, 2010.

WATANABE, Kazuo. Da cognição no processo civil. 2. ed. Campinas: Bookseller, 2000. 